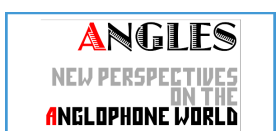

ANELOPHONE WORLD

\section{Angles}

New Perspectives on the Anglophone World

$11 \mid 2020$

Are You Game?

\title{
Churches, City and National Identity in Mid-19 Century Edinburgh
}

\section{Clarisse Godard Desmarest}

\section{(2) OpenEdition}

1 Journals

\section{Electronic version}

URL: https://journals.openedition.org/angles/2302

DOI: $10.4000 /$ angles. 2302

ISSN: 2274-2042

\section{Publisher}

Société des Anglicistes de l'Enseignement Supérieur

\section{Electronic reference}

Clarisse Godard Desmarest, "Churches, City and National Identity in Mid-19 ${ }^{\text {th }}$ Century Edinburgh", Angles [Online], 11 | 2020, Online since 01 November 2020, connection on 06 June 2022. URL: http:// journals.openedition.org/angles/2302 ; DOI: https://doi.org/10.4000/angles.2302

This text was automatically generated on 6 June 2022.

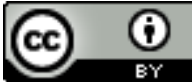

Angles est mise à disposition selon les termes de la Licence Creative Commons Attribution 4.0 International. 


\title{
Churches, City and National Identity in Mid-19 $9^{\text {th }}$ Century Edinburgh
}

\author{
Clarisse Godard Desmarest
}

\section{Introduction}

As the days lengthen towards the close of May, and the foliage grows thicker in the Princes-street and Queen-street gardens, an unusual influx of black coats and white neckcloths announces the season of the annual meeting of the Scottish Convocation, the Supreme legislative and judicial court of the Kirk, the General Assembly of the Church of Scotland. The ecclesiastics of Scotland have chosen for their meeting [...] twelve days divided between the latest of May and the earliest of June [...] the streets swarm with clergymen of every possible diversity of appearance, and from every corner of Scotland [...] not only does the General Assembly of the Kirk meet at this time, but also that of the "Free Church," which has closely copied the organization of the national establishment: there are more clergymen, for the time, in Edinburgh than there are priests in Rome. (Fraser's Magazine 1856: 1)

1 This quote is from an article entitled "Edinburgh during the General Assembly." The Free Church was established in 1843, when 450 evangelical ministers of the Established Church broke away under the leadership of the Rev. Thomas Chalmers (1780-1847) mainly over the issue of the Church's relationship with the State, an event known as the Great Disruption and whose principle goes back to Andrew Melville who advocated, in the Second Book of Discipline (1578), the 'two kingdoms' theory whereby the Church and the State were deemed separate spheres of influence (particularly on the thorny issue of patronage). The Disruption was an event "by which the greater part of the evangelical clergy of the Established Church voluntarily relinquished their livings and their resources, rather than yield to the Erastian principles adopted by the civil government", as explained by the Rev. Dr. Duff, Moderator of the Free Church in 1851 (The Biblical Repertory and Princeton Review 1851: 575). In this new Reformation aiming to restore the spiritual independence of the Church - Chalmers famously declared "let kings retain their sceptres and nobles their coronets" (Watt 1946: 4) - and the purity of 
doctrine, the training of divinity students who had joined the Free Church and would train students for the ministry was deemed essential. The Free Church's new training college was opened in 1846 on the Mound (as will be explained later), next to Victoria Hall, the recently-opened building which housed the headquarters of the rival Church of Scotland:

The tourist or visitor from the south, who has sauntered along that unrivalled Princes-street, must have observed, high up on the Castle Rock, a little way down the slope towards Holyrood, a noble spire, of, we believe, some two hundred and fifty feet in height, and in its design not unworthy of Pugin. That spire marks the position of "The Assembly Hall," a handsome Gothic building, which was erected at a vast expense for the use of the General Assembly, and is so arranged as to be used as a church during the remainder of the year. (Fraser's Magazine 1856: 2)

2 Rather unusually for a paper which argues its topic has a global context, the prime focus will be here on the two buildings mentioned above - Edinburgh's Victoria Hall and the Free Church College. It has been argued that these two buildings inaugurated a transitional period when the old Town, all but rejected by the $18^{\text {th }}$-century 'Improvers', was regenerated. My wider aim is to show how the urban landscape and the historic setting of Edinburgh, revived for the purpose as Scotland's ancient capital, was used by two rival national Churches to each assert its significance and historic entitlement; and to suggest that the impact of each building as rival headquarters was not just local, but national, and indeed - in the context of British Empire, colonialism and maritime commerce - global. This conclusion is drawn by studying a tiny hub of only two buildings which almost touch each other in the Old Town, within immediate proximity to the Castle. This paper therefore fixes upon a moment in history and a location in central Edinburgh that is rich in cultural, ecclesiastical, urban and architectural history. The story of this episode and site has been previously referred to in other Scottish publications, but it has not been pulled together in a comprehensive manner, partly because different specialists have approached it from their own points of view, whereas this paper will examine together the story's ecclesiastical, urban and architectural aspects.

3 This paper further argues that by the mid-19 $9^{\text {th }}$ century, the Lawnmarket area formed a 'holy corner', and all this new building was in proximity to the ancient cathedral ${ }^{1}$ or High Church of Edinburgh, St Giles, further down the High Street towards Holyrood Palace. Viewed from Princes Street, the Free Church building and the Church of Scotland building, both in dialogue (as discussed below), had a dominating presence in the urban landscape - as also had the nearby Bank of Scotland building (by Richard Crichton \& Robert Reid, 1806), deeply plain, until extravagantly reconstructed in swaggering baroque in 1864 (by David Bryce [1803-76]) to match the churches' aesthetic vigour.

\section{Victoria Hall and the Lawnmarket area}

In the late 1830s, the Church of Scotland decided to build a new assembly hall at the top of the Lawnmarket; because of the national status of the Church, it would be called Victoria Hall, after the monarch, and would be paid for by public funds. Of the total cost of $£ 16,000$, the Town Council paid $£ 6,000$ and the Treasury the rest, including $£ 3,600$ for the site. It was erected under the provisions of the Edinburgh Improvement Act of 1827. This building is the result of a request addressed by the Treasury to the Commissioners 
of Woods and Forests (officials charged with the management of Crown lands) "to consider and report the most economical arrangement that could be made for providing a proper place of meeting for the General Assembly and the Royal Burghs, in lieu of the present Aisle". ${ }^{2}$ In 1834, the General Assembly complained of bad acoustics in St Giles; on 13 June 1834, the Committee of Woods and Forests replied with a report (dated 30 May 1834) by Robert Reid (1774-1856), the Master of Works in Scotland (royal architect), who suggested means of getting rid of the echo sound which would be necessary if the aisle became a church. Reid wrote "that in every other respect the present Hall is most admirably suited to the meetings", and he added that he did not imagine that any satisfactory site could be procured on which to build a new place of meeting. ${ }^{3}$ On 25 March 1836, following the reports produced by two Edinburgh architects, William Burn (1789-1870) and William H. Playfair (1790-1857), the Commissioners of Woods and Forests "had arrived at the conclusion that no alteration that could be made in the Aisle of St Giles Cathedral [that] would be likely to make that building suitable for conducting the business of the General Assembly, and that the only way of bringing the matter to a satisfactory result is to build a New Hall". ${ }^{4}$ The Treasury suggested selling the aisle to the City as a church and recommended the restoration of Holyrood Abbey as a hall-cum-church; the Abbey kirk had been abandoned as a ruin when its roof collapsed in 1768. James Gillespie Graham (1776-1855) was consulted on the potential restoration of the roofless building, and his estimate in April 1837 was $£ 20,276$ (excluding professional fees), but the Treasury was not prepared to go ahead with the work. ${ }^{5}$

5 A rumoured Castle Hill site was not considered suitable by the General Assembly. ${ }^{6}$ However, on 24 December 1838, the City agreed to cooperate in providing the General Assembly with a Hall on condition that it be used also as a church, and suggested two sites (Castle Hill and Parliament Square), and the Treasury had plans for a church for Parliament Square (plans by Robert Reid) and also a ground plan of the Castle Hill site. The Treasury eventually decided on the Castle Hill site on 11 January 1839 and on the cost detailed above. A rival of Robert Reid and a man of incredible ambition, James Gillespie Graham secured this nationally important commission and his plans (drawn by Augustus Welby Northmore Pugin [1812-52], Graham's amanuensis) were approved in November 1839. The architect sent working drawings in March $1840 .^{7}$ It is said that Gillespie Graham and Pugin befriended when the latter was ship-wrecked off the coast at Leith, and several of Gillespie Graham's buildings benefited from Pugin's prodigious talent and knowledge. ${ }^{8}$ As detailed in the Dean of Guild Petition, dated 4 February 1841, "The said new Church and Assembly Hall is to have three parts - the North front facing the street of the Castle Hill, the south front facing the new west approach to the city, and the east front looking to the West Bow and the Lawnmarket" (Figures 1-3). ${ }^{9}$ No objections were made by the proprietors of the adjoining tenement, called Rockeville House or Rockeville's Land, to the west of the area where the church was planned to be built. 
Figure 1: Victoria Hall, Outline of Ground and Plan of the Assembly Hall to be erected on the Castle Hill by Pugin and Gillespie Graham, 28 January 1841

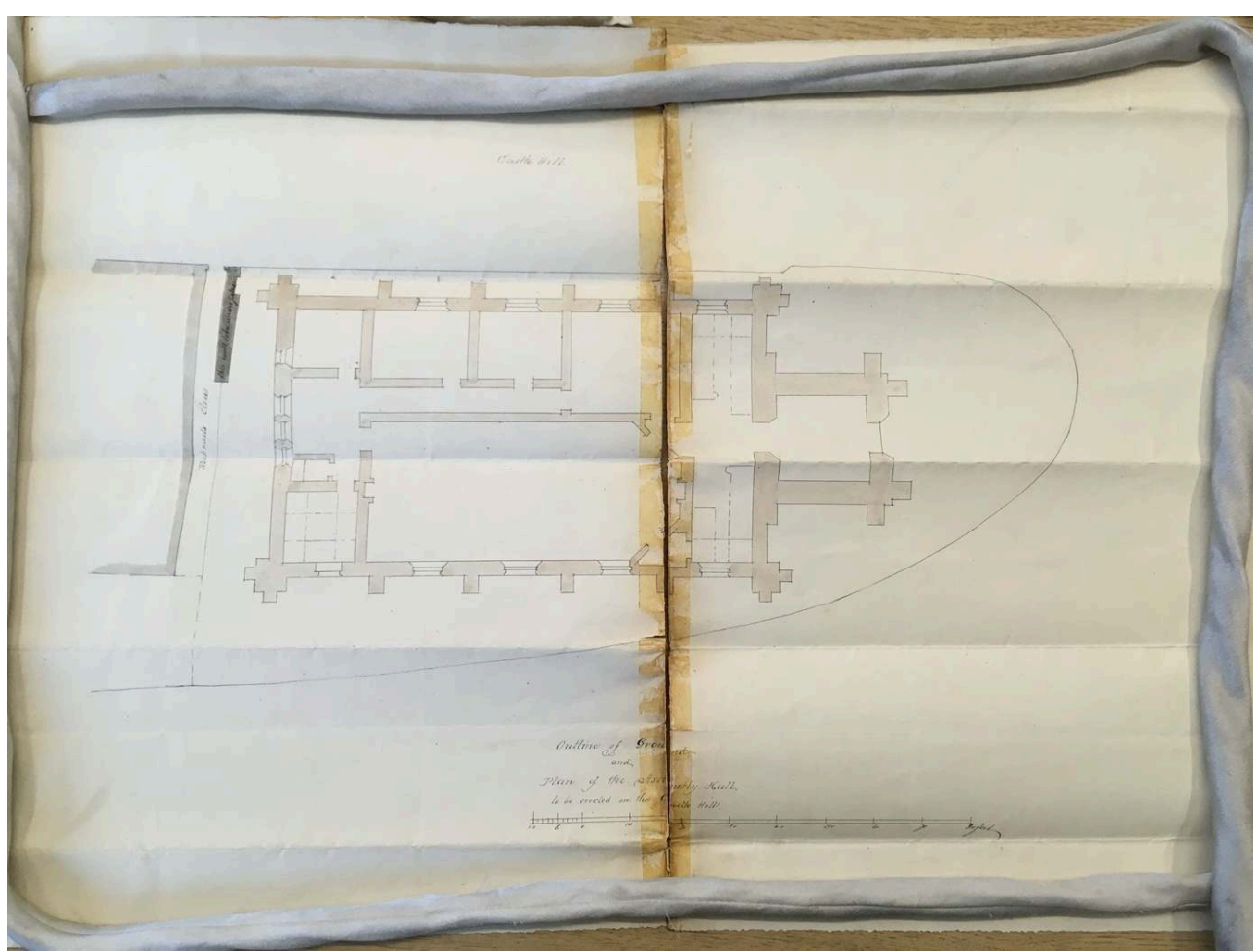

Copyright Edinburgh City Archives.

Figure 2: Victoria Hall, South Elevation of the Assembly Hall to be erected on the Castle Hill by Pugin and Gillespie Graham, 28 January 1841

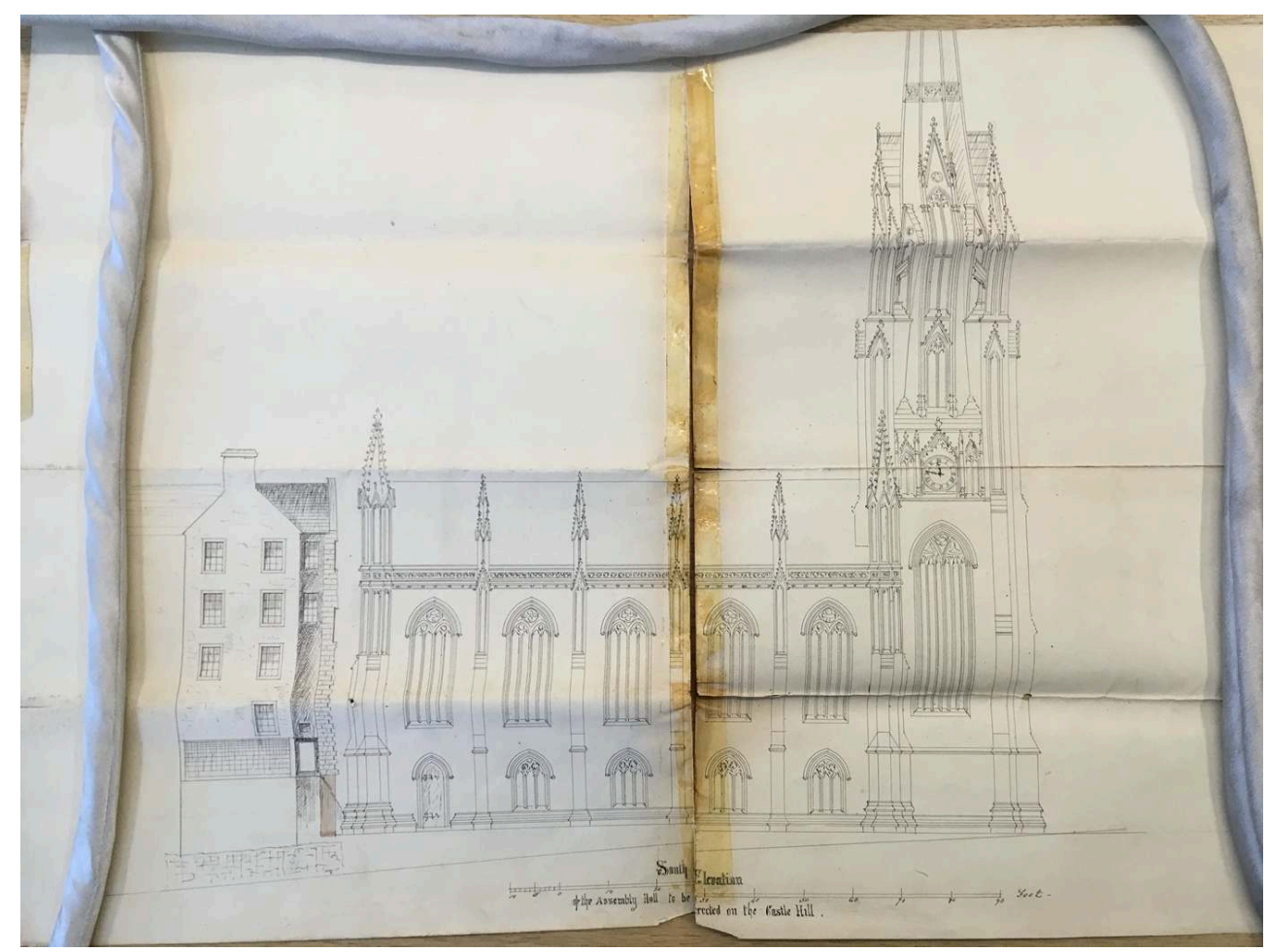

Copyright Edinburgh City Archives. 
Figure 3: Victoria Hall, Elevation of East or Entrance Front of the Assembly Hall, Castle Hill, 28 January 1841

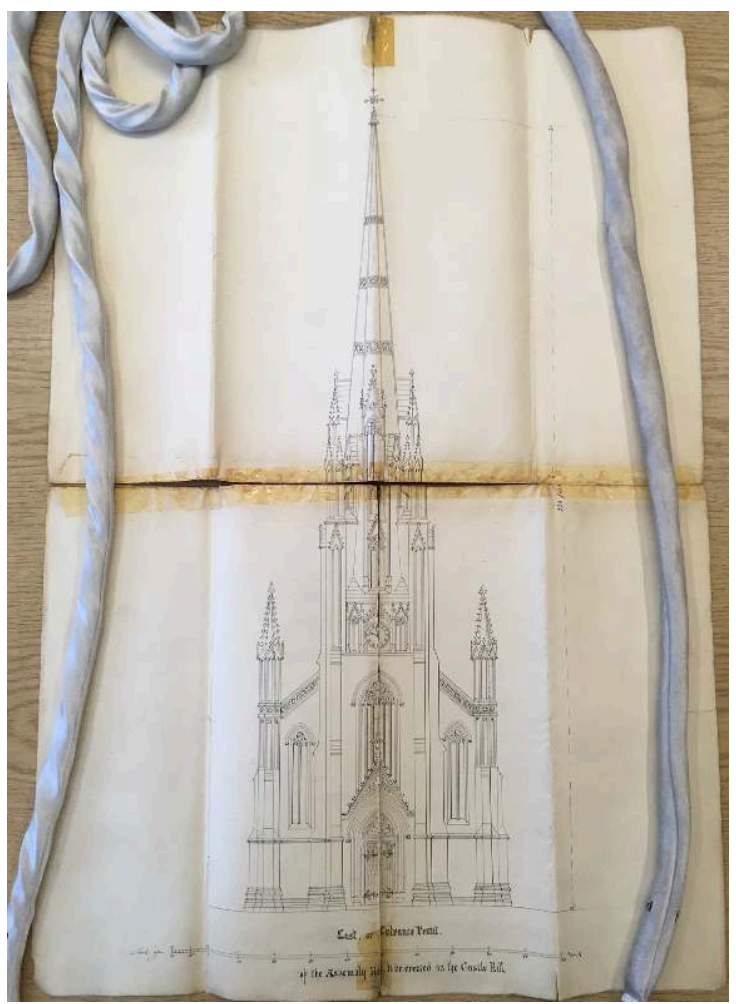

Copyright Edinburgh City Archives.

6 Victoria Hall (afterwards the Old Tolbooth Church), on Castlehill, was built in the Gothic style by Gillespie Graham and Pugin, 1841-44, at a cost of about $£ 16,000-$ John Lind was the master builder (Groome 1901: 515) (Figures 4-7). 
Figure 4: Victoria Hall, east entrance front, viewed from intersection of Castlehill, Johnstone Terrace and Lawnmarket

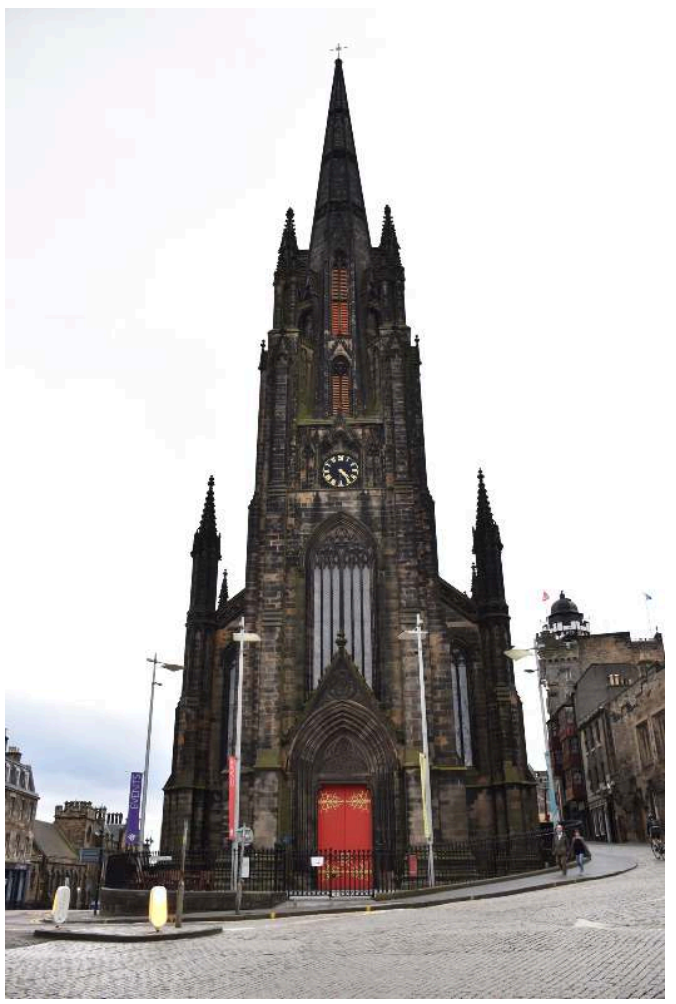

Picture taken by the author.

Figure 5: Victoria Hall, north front, viewed from Castle Hill Street

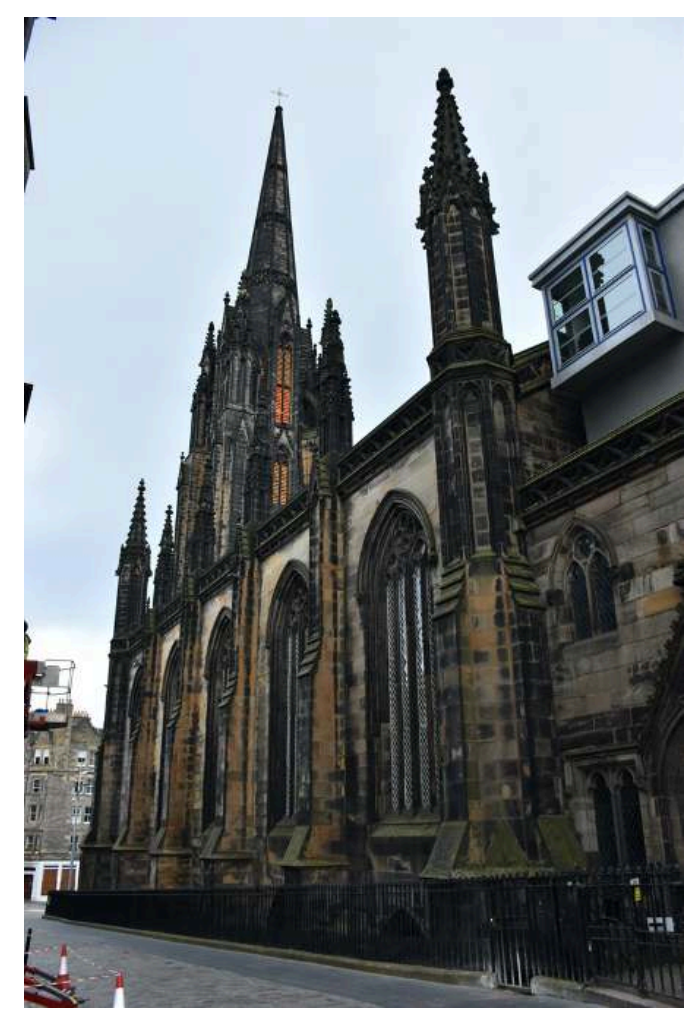

Picture taken by the author. 
Figure 6: Victoria Hall, south front, viewed from Johnstone Terrace

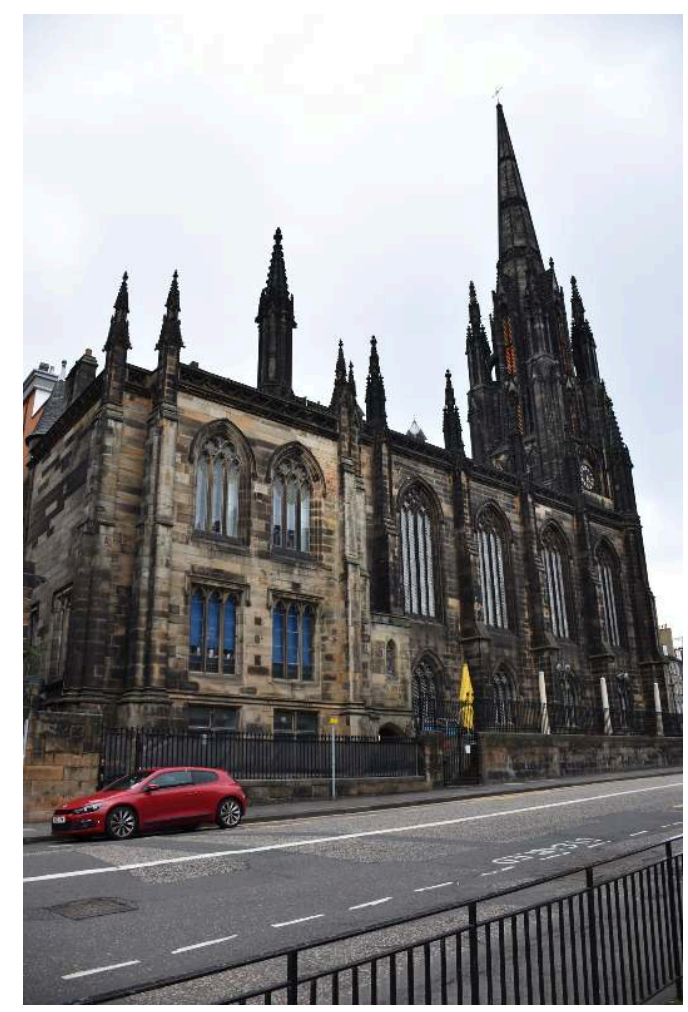

Picture taken by the author.

Figure 7: Hill and Adamson, View of Victoria Hall, and St Columba's Free Church, 9 September 1844

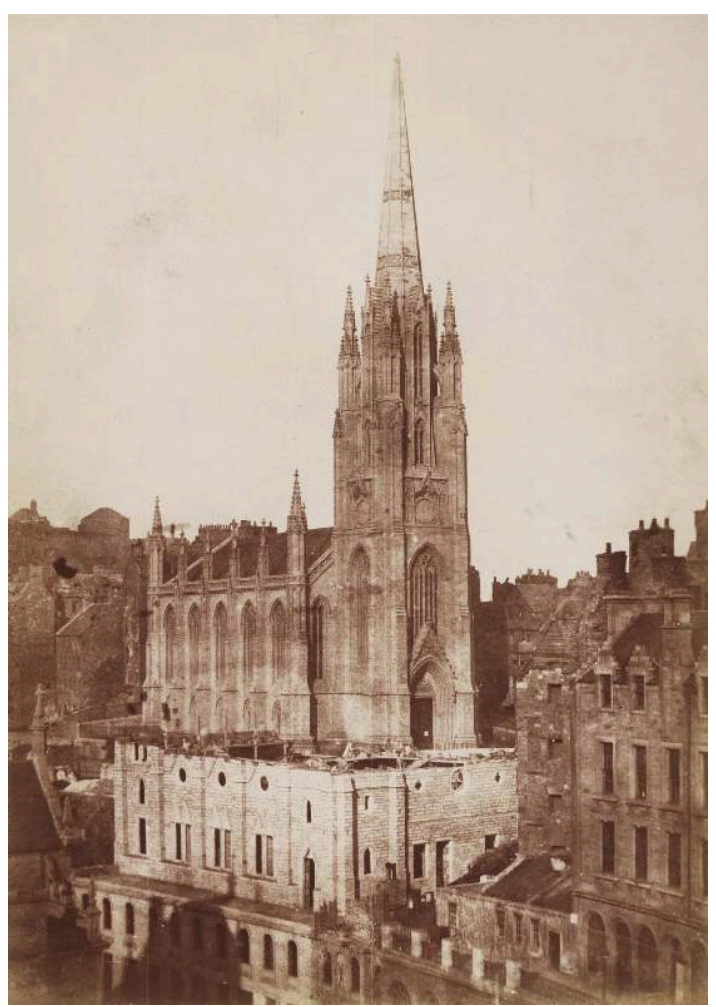

Copyright Getty Museum. All rights reserved. 
7 Pugin, in the background, had helped Charles Barry (1795-1860) (and, ironically, Gillespie Graham) in the Houses of Parliament competition at Westminster, which Barry won (Macaulay 1984: 406-420). Prior to the opening of Victoria Hall, the 1841, 1842 and 1843 General Assemblies were held in St Andrew's Church, George Street. In the 1820s remodelling of St Giles, William Burn had made provision for the Assembly to occupy its southern part, creating an enlarged hall for it (Glendinning 2004: 211). The pre-reformation church of St Giles (with fabric dating back to the $12^{\text {th }}$ century), with a catholic liturgical plan, had been adapted since the $16^{\text {th }}$ century for Protestant worship and had been subdivided into four churches. By the 1840s, these were found to be inadequate and the church, in any case, was subject to remodelling as part of an important new urban design that was mainly concerned with linking up the old Town with the New Town and with both the southern and western suburbs. ${ }^{10}$ Attention, therefore, now focused on the upper end of the old Town, where an improvement scheme conceived in 1824 by Thomas Hamilton had begun to advocate new bridges and vistas.

The Lawnmarket, that area of the main street of the old city that connected the castle to St Giles, lay at the heart of this urban development, and the two new buildings discussed in this paper sit right in the middle of this developing area. The urban significance of these two buildings is key to their interpretation. John Bartholomew's map of Edinburgh, 1864, for the Post Office Directory shows this new development, and the two churches are noted 'Assembly Hall' and 'Free Church College' (Figure 8). Victoria Hall is in clear view from the Castle esplanade, and from Princes Street and Hanover Street in the New Town (Figures 9-10).

Figure 8: John Bartholomew, Plan of Edinburgh \& Leith with Suburbs, from Ordnance and Actual Surveys. Constructed for the Post Office Directory, 1864 (detail)

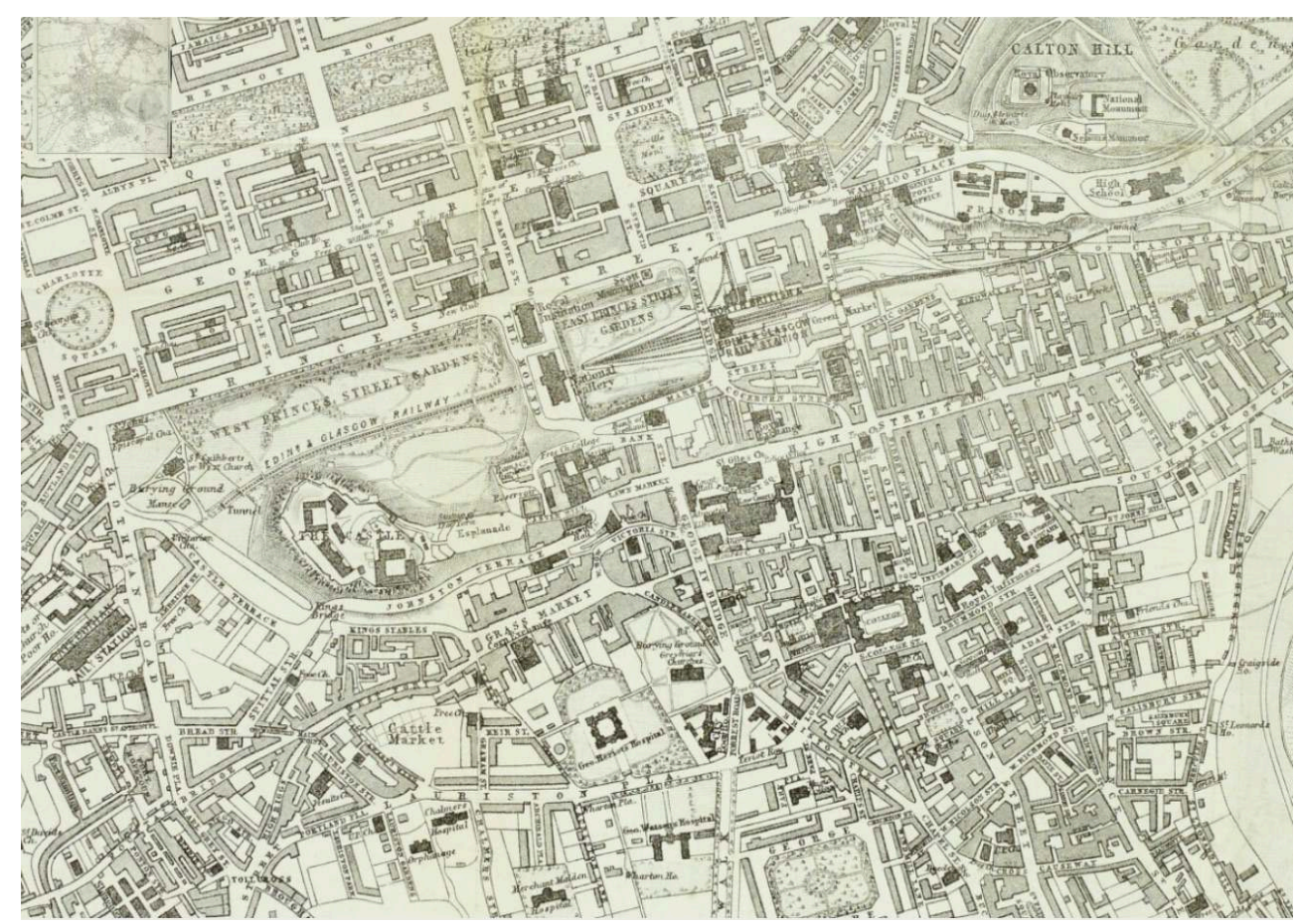

John Bartholomew's map shows the 'Assembly Hall' and 'Free Church College' on either side of the Lawnmarket.

Source: https://maps.nls.uk/towns/rec/5330. 
Figure 9: Victoria Hall, viewed from the Castle esplanade

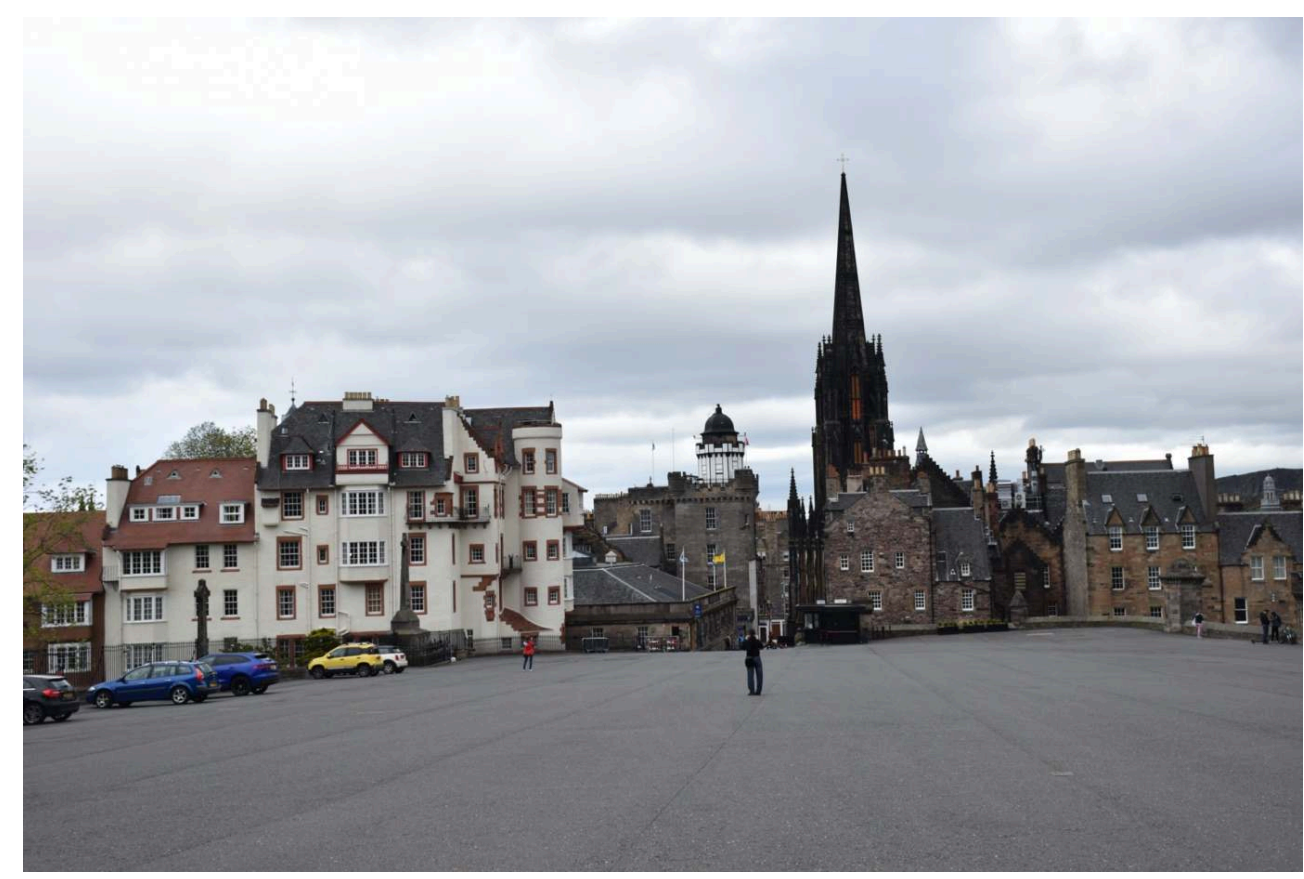

Picture taken by the author.

Figure 10: Victoria Hall, viewed from from Princes Street and Hanover Street in New Town

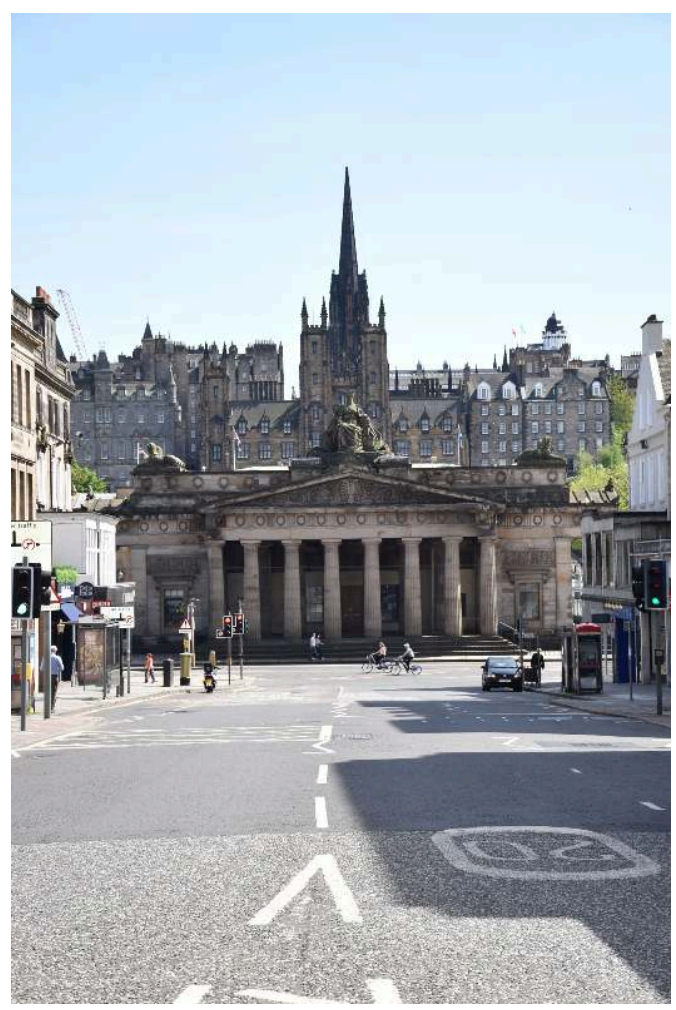

The spire of Victoria Hall appears between the twin square towers of Free Church. Picture taken by the author. 
As explained above, the new building was designed and built to serve both as a church for the Tolbooth congregation and the meeting hall of the General Assembly of the Church of Scotland; it kept this dual role until 1929, when the reunion of the United Free Church with the established Church of Scotland reversed the Disruption of 1843 and resulted in the merging of the University's faculty of divinity with its former Free Church rival, New College. According to John Gifford, Victoria Hall was the ideal parish church of Pugin's True Principles of Christian Architecture (first published in 1841):

An old English parish church, as originally used for the ancient worship, was one of the most beautiful and appropriate buildings that the mind of man could conceive; every portion of it answered both a useful and mystical purpose. There stood the tower [...] formed of [...] solid buttresses and walls rising from a massive base, and gradually diminishing and enriching as they rise, till they were terminated in a heaven-pointing spire surrounded by clusters of pinnacles [...] (Pugin 1895: 42)

This praise notwithstanding, ironically, Pugin had converted to Catholicism in 1835 and was critical of the Scottish Kirk.

The church not only has the tallest spire in Edinburgh but is the highest building in the city. The spire was described admiringly in the Ordnance Gazetteer:

At each corner [of the church] is a richly adorned pinnacle, and at the east end is a massive tower containing the chief entrance. The buttresses at the corners of the tower terminate in pinnacles, and from its top springs a handsome octagonal spire, which rises to a height of 241 feet, and forms a very prominent object in many of the views of Edinburgh. (Ordnance Gazeteer of Scotland 1901: 515)

The church stands prominent in the heart of the old Town amidst tall, mainly $17-18^{\text {th }}$ century tenements, where, it was observed, there seems to be "some ecclesiastical gravitation to the spot" (Fraser's Magazine 1856: 2). By 1856, within immediate distance from the Assembly Hall, featured St Columba's Free Church (originally Free St John's) (by Thomas Hamilton, 1845) (Figure 11), and St Columba by the Castle Episcopal Church (14 Johnston Terrace) (by John Henderson, 1846-7) (Gifford 1984: 167-8). 
Figure 11: St Columba's Free Church (originally Free St John's)

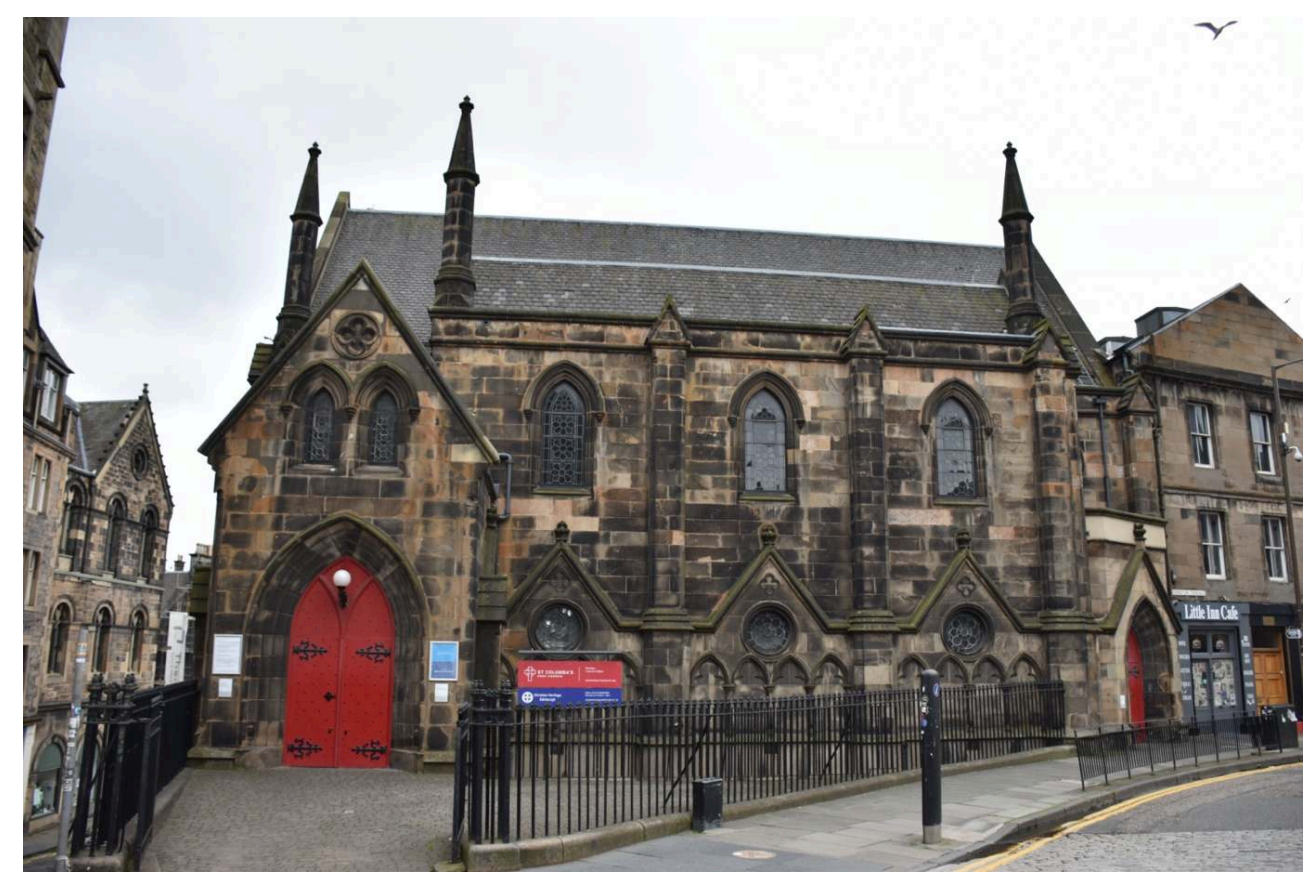

Picture taken by the author.

13 Access to the Lawnmarket from Castle Terrace to the west had been made possible thanks to the new 'west approach' (Johnston Terrace), which skirted the Castle on the south (Lizars 1856). Also nearby, in Victoria Street, was St John's parish church (by George Smith, 1838). And by 1865, on Victoria Terrace (above Victoria Street), there stood also a tall-windowed Quaker church (ECA Dean of Guild 16 June 1865; The Builder, 19 August 1865) and a 3-bay Italian gothic church (now Baden-Powell House), each by Paterson and Sheills (ECA Dean of Guild 15 April 1865; The Builder, 4 November 1865).

\section{Victoria Hall, a citadel of British royalism}

Before Victoria Hall was built, Pugin produced a design (unexecuted) for Glasgow Cathedral, providing what appear to have been big identical twin steeples for the west front, in 1837. This was also the year the Holyrood Abbey kirk scheme (also by Pugin, 1836-7) was rejected, the year of the coronation of Queen Victoria, and of future Prime Minister Sir Robert Peel's banquet in Glasgow. (A concern had arisen that Glasgow's unequal west steeples were unsuitable, and they were demolished in 1846 and 1848).

As built by Gillespie Graham and Pugin, the imposing church and hall of the General Assembly (Victoria Hall) in Edinburgh takes up the whole upper floor. The processional layout survives, beginning at the entrance door under the tall spire, passing through first a handsome vaulted lobby, then along a deep passageway, which on either side had committee-rooms and other official chambers, continuing the full length of the building so far as the grand staircase at the far end. Upstairs, lit by wide windows, the church has a groined roof (flat, and its wide span is remarkable for its time), a deviation from the canons of Gothic architecture because Presbyterian worship sought to render audible voices speaking from any part of the hall. Improvements to the Hall's acoustics were carried out in the mid-1850s. ${ }^{11}$ The room is dominated by a dais, elevated about 
six feet above the floor of the house, and enclosed in a massive oak railing. In the centre of this platform stands the throne bench, the seat for the Lord High Commissioner to the General Assembly - the monarch's representative, almost always a Scottish nobleman. The throne was an item of importance, as shown by a letter from Gillespie Graham to the Commissioner of Her Majesty's Woods and Forests: "I have given the most mature consideration to the Designs for the Throne"; two designs were prepared by Gillespie Graham (i.e., Pugin) in 1843, with estimates from Edinburgh upholsterer Charles Trotter ( $£ 155$ and $£ 218$ each). ${ }^{12}$ The Throne Gallery could accommodate 40 to 50 people. Immediately in front of it, on a slightly raised platform, stood the chair of the Moderator, who sat with his back towards, but beneath, the Commissioner. Other senior members of the Church sat around a large table before the Moderator's chair. To the right and left of the Moderator's chair were benches. In 1869, it was observed (perhaps light-heartedly) of these benches that those to the right were occupied by the 'Moderate' or 'Conservative Party' and those to the left by the 'High flying' or 'Movement party'; and that because of the disposition of the seats and the personalities in the Church, debates could compare with those in the House of Commons (Tinsleys' Magazine 1869: 595). Facing the throne was a large gallery; allotted to students of theology and members of the public. The members' part of the hall could accommodate 600 people; the entire building about 1300. The Royal Arms in front of the Gallery opposite the throne were provided by Trotter (who doubtless charged his estimated cost of $£ 23$ ), the steeple bell by Messrs Mears, bell-founders in White Chapel, London (they estimated $£ 140,15,4$ ) and both Robert Bryson and Son and James Ritchie and Son provided estimates for the clock in the steeple (of $£ 216$ and $£ 176$ respectively). ${ }^{13}$ The pulpit, Gothic chairs, ironmongery, grates and stoves were all made according to designs by James Gillespie Graham (i.e., the important designs at least, by Pugin). ${ }^{14}$

According to Fraser's account of the opening of the Assembly in 1865, addressing the Commissioner who is sitting on the throne, the Moderator, a Doctor of Divinity and a clergyman of many years' standing, has to testify "the affection of the church to the Throne". Also, "The Commissioner in his speech expresses the attachment of the monarch to the Church of Scotland, and the resolution of the monarch, under all circumstances, to maintain the rights and privileges of the church"; the Commissioner is also in charge of reading a letter from the sovereign to the Assembly. Although the Commissioner (representing the Sovereign, and the secular authority) and the Moderator (a representative of the Congregation and of God's Word) appear superficially to be on the best of terms, the relationship between the two was certainly not always easy, as shown by the ending of proceedings described here in the author's bitter irony:

It was curious to see the little proof of the mutual jealousy of the Church and the State, in this form of dissolving the present Assembly, and appointing the time of meeting of the next; the Moderator doing so in the Saviour's name, without the least recognition of the Queen's power to interfere; and the Commissioner doing so in the Queen's name, without any notice of the previous words of the Moderator. Long may the spiritual and temporal powers work together harmoniously as now, without hitch or hindrance! (Fraser's Magazine 1856:17)

17 The Presbyterian form of government was in fact guaranteed by the monarchy and in the 1707 Act of Union with England, before the British Parliament restored patronage in 1712 against the wishes of the large majority in the Scottish Church. The foundation ceremony took place on 3 September 1842 by Lord Frederick FitzClarence, the Grand 
Master Mason of Scotland, in the presence of the Lord Provost, Sir James Forrest, and the Moderator, Rev. Dr. David Welsh. Taking nothing to do with the ceremony, the Queen, on her first visit to Scotland, waved at the attendees both on her way uphill to the Castle and when she passed them again on her return downhill. Dick Lauder referred to "the Victoria Hall as the building is henceforward to be called", and quoted the document inset within the foundation stone whose inscription included:

To the Glory of God, in Honour of THE QUEEN, on the 3d day of September MDCCCXLII The Day of Her Most Gracious Majesty QUEEN VICTORIA Visiting the City of Edinburgh, THE RIGHT HONOURABLE SIR JAMES FORREST OF COMISTON, BARONET, Lord Provost, The Reverend David Welsh, DD, Moderator of the Assembly, the Foundation Stone of this Superstructure, to be Called VICTORIA HALL for the use of the GENERAL ASSEMBLY OF THE CHURCH OF SCOTLAND, was laid by THE RIGHT HONOURABLE LORD FREDERICK FITZCLARENCE, GCH, \&c., Grand Master Mason of Scotland, in presence of the Grand Lodge, and other Masonic Lodges. JAMES GILLESPIE GRAHAM OF ORCHILL, ARCHITECT. John Lind, Master Builder of the Hall. Length, from East to West, 141 Feet, Height of Spire over the Entrance, 241 feet. (Lauder 1843: 115)

In that document, God was mentioned once; Victoria twice - or thrice, should we count referencing the building's name; and each was in bolder lettering than God. The name 'Victoria Hall', however, sounded discordantly on the ear of many: "How strange that the holiness of purpose which has been so carefully uttered in stone should be denied in name! Victoria Hall! Why, Minerva Temple would hardly have a more heathenish twang!" (Fraser's Magazine 1848: 491). Victoria Hall was at that point arguably Scotland's greatest public building project of the century. The wish to highlight its two longest dimensions in the document quoted above indicates the creators' pride in it. It was built by and for the Established Church which had a leading role in propagating loyal devotion to the monarch. It would become the tallest building in the Scottish capital, and a citadel of British royalism.

\section{The Free Church of Scotland's headquarters, a building in the English collegiate style}

19 Between 1842 and 1843, tension within the Kirk rose over patronage with the evangelicals. The result was the 1843 Disruption (Brown 1996: 29-50). At the opening of the Assembly on 18 May 1843 in the temporary venue of St Andrew's Church in George Street, the retiring moderator (David Welsh) denounced the royal court's interventions (which some considered to be meddling where the Crown had no role) as intolerable erastianism, and led out $40 \%$ of the clergy, 474 out of the 1,195 present. The procession headed downhill to Tanfield Hall, where each individual signed a 'Deed of Demission' giving up their livings. There, they convened the first General Assembly of the newformed Free Church of Scotland.

Customarily, during the ceremonial of opening of the sessions of the General Assembly of the Church of Scotland, the usual procession of the Lord High Commissioner was from Holyrood Palace to St Giles's, via Abbey Hill, Calton Hill, Waterloo Place, North Bridge and High Street, eventually reaching the High Church (which, as we saw, was a sub-division within St Giles). The Free Church, by contrast, sought independence from the monarch: 
At a meeting of the "Free Church" party in Edinburgh, an unhappy individual named Hetherington, a minister of that "body" [...] spoke to the following effect: "The Church of Scotland! It is no church at all! It is a mere engine of State domination! It is a traitor church: a Scottish traitor, which is worst of all: a traitor like him who betrayed Wallace to the English!" (Fraser's Magazine 1856: 11)

The opinion of the friends of the Free Church had been that "an architectural building for the accommodation of her college, in the centre of the metropolis, would be becoming her position as a National Institute". ${ }^{15}$ The purchase of the site at the head of the Mound, announced at the 1844 Assembly, amounted to £10,000; admittedly, "no better [site] could have been found had we searched all Scotland" (Brown 1884: 332). Funding was made possible thanks to the active exertions of Rev. David Welsh, with the intention that no direct appeal be made to the Church in order to prevent imposing any burden on the Church at large. Previously, in June 1843, the Free Church had purchased a house at $n^{\circ} 80$ George Street, which it altered to provide the necessary provisions for a training college. ${ }^{16}$ On account of the George Street premises being quickly considered too small, a public competition for the erection of suitable college buildings was launched in September 1844. The Church was optimistic that it would grow, and indeed, by 1847, the number of students who matriculated at the New College was 300 . 17

Twenty-five competition entries, plans and designs, were lodged for this purpose-made building. The designs were displayed for some time in a large hall in George Street (perhaps the Free Church's own hall in 80 George Street) for the friends of the Church to see. Professional expertise to judge the design was considered necessary and charles Barry, the celebrated architect of the Houses of Parliament, was invited to advise by Alexander Earle Monteith, advocate, and the convenor of the building committee. ${ }^{18}$ As an outsider, Barry might have been thought less likely to show bias amongst Scottish architects, and his celebrity status meant that some might have considered him the de facto head of the profession in the UK. According to Ian Gow, "When the Free Church, who were architecturally ambitious, got hold of the land behind his building [ie. Royal Institution], Playfair felt a proprietorial interest, and must have been alarmed when the design was put out to competition and Barry was invited to help select the winner" (Gow 1984: 53). Barry selected two designs; one bearing the motto 'Labor ipse voluptas' and one numbered ' 379 '. He responded thoughtfully:

[...] each has its practical as well as aesthetical advantages over the other; but their respective merits are very nearly equal, apart however from the consideration of cost. I am inclined to prefer the Design $n^{\circ} 379$, on account of the concentration of nearly the whole of the class rooms upon one floor, and also on account of the symmetrical principle and imposing extent of the North Front, which in my opinion is better suited to the situation proposed for the intended Building, than the North Front of the rival design; but as in the conditions of the competition considerable importance is attached to the point of economy, and as I feel some doubt whether the Design $\mathrm{N}^{\circ} 379$ can be executed within the amount prescribed by the terms of the competition, I have no hesitation in stating that the author of the design bearing the motto 'Labor ipse voluptas' is in my opinion fairly entitled to the first premium. 19

23 Although they displayed considerable taste and talent, neither of the two designs was considered wholly suitable. A second competition, on a more enlarged and literal plan, this time for accommodation for the College and a Church, was launched; old houses on the site were removed in August $1845 .^{20}$ 

was similarly deemed unsuccessful, a professional architect was finally appointed. The commission was awarded to Playfair, whose close friend, Lord Rutherford, the Lord Advocate, was a prominent Free Church member - by this stage, the Free Church was lavishly financed, and was therefore able to fund the construction of a theological college in Edinburgh on a grander scale than the competition entries had been asked to provide. This was one of Playfair's few but highly-significant post-University commissions (he had modified and completed Robert Adam's building 1817-26), as were also Donaldson's Hospital (1842-54) and the National Gallery of Scotland (1850-57) (Haynes and Fenton 2017: 67). In October 1845, Playfair brought forward a design which was approved of by the building committee; the entire college at a cost originally estimated at $£ 30,000$, and a portion of the design at $£ 20,000 .{ }^{21}$ This portion of Playfair's design, first contracted for (and executed), was to "form a Building very complete in all its parts, as it will embrace the whole of the lower quadrangle" with the following: seven classrooms, professors' retiring rooms, public library, librarian's room, reading room, museum, conservator's room, senate hall, porter's lodge, room for public documents, one church, vestry, session room, water closets, and cellars and also a house for the principal of the College. ${ }^{22}$ Playfair indicated that

when the whole plan shall be completed there will be in addition to the accommodation enumerated above: a proper and permanent museum, a chemistry classroom with apparatus room \& working laboratory to serve as a classroom of practical chemistry. A natural philosophy classroom with apparatus room, all with retiring rooms, together with two other classrooms making eleven classrooms in all. Instead of 7 as now proposed. If the Principals House be thought superfluous it can be made to contain various small classrooms instead. ${ }^{23}$

The foundation stone for the Free Church's training college was laid on 4 June 1846, the ultimate cost being $£ 46,506$ 8s. 10d, including the price of the ground, $£ 10,000$ (Grant 1885: 97-8). Playfair wrote about the ceremony: "I hear from Mr Smith the contractor for the New College, that yesterday, Dr Chalmers unknowingly broke the bottle when putting it into the stone. He said nothing at the time for fear of creating confusion. I have ordered a new bottle [...] I intend to see the whole replaced myself". ${ }^{24}$

The warrant to erect the New College (Figure 12), on the south of the road leading from the head of the Earthen Mound to the Castle Hill, was issued on 29 October 1846, with four plans by Playfair dated 15 July 1846 (ground plan, elevation of the north, south and east external fronts) (Figures 13-16). ${ }^{25}$ As for the timing of completion, the builders agreed to "finish and give possession of the whole of the college buildings, on the first day of November 1849. The Church forming the east side of the quadrangle, to be finished by the first day of November 1848". ${ }^{26}$ 
Figure 12: Free Church College, north front, viewed from the Mound

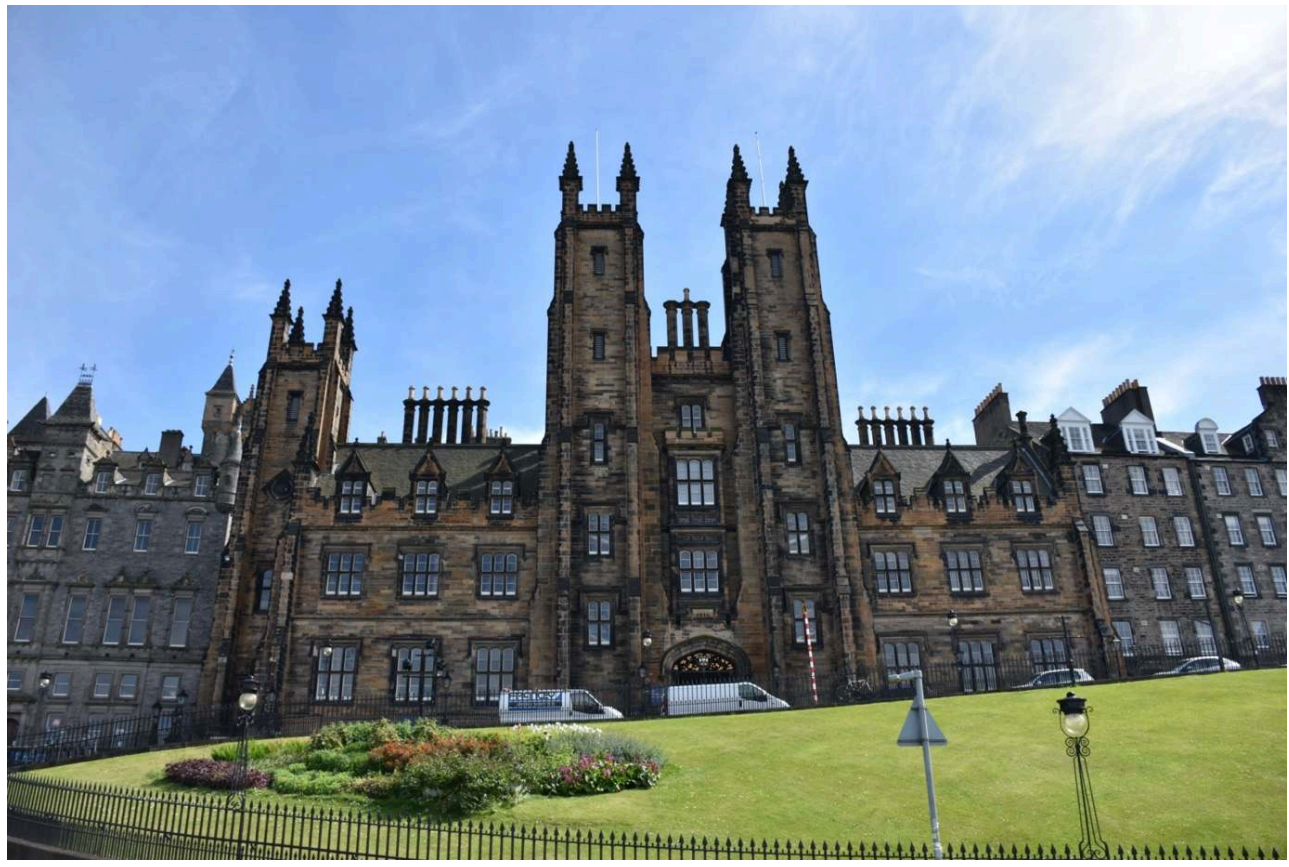

Picture taken by the author.

Figure 13: The New College of Edinburgh, General Plan by W.H. Playfair, 12 August 1846

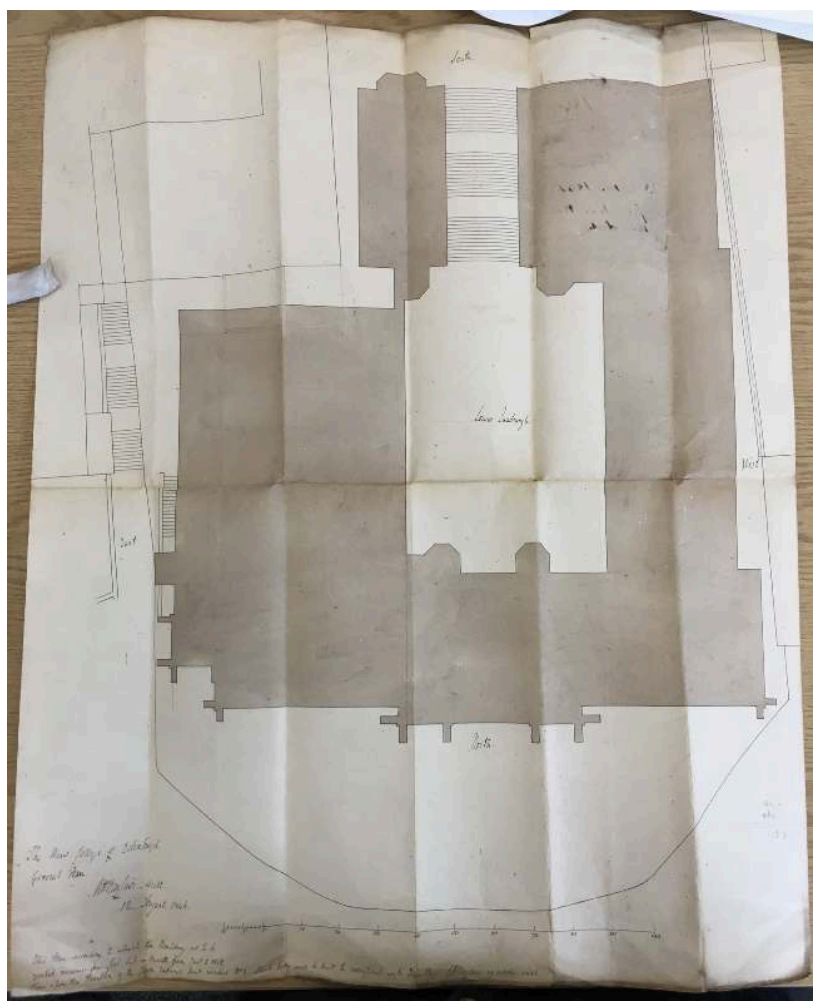

Copyright Edinburgh City Archives. 
Figure 14: The New College of Edinburgh, Elevation of the South External Front by W.H. Playfair, 15 July 1846

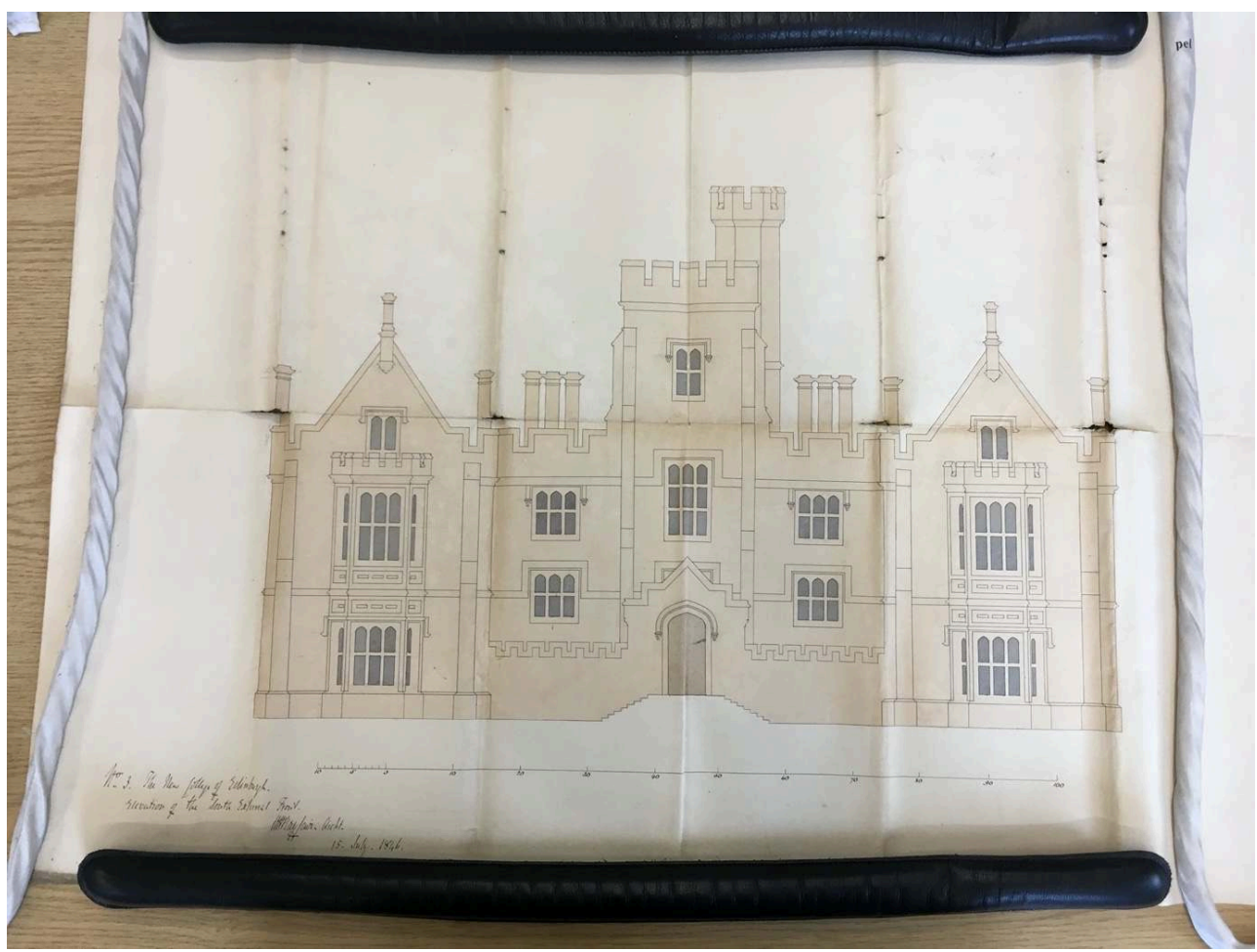

Copyright Edinburgh City Archives.

Figure 15: The New College of Edinburgh, Elevation of the North External Front by W.H. Playfair, 15 July 1846

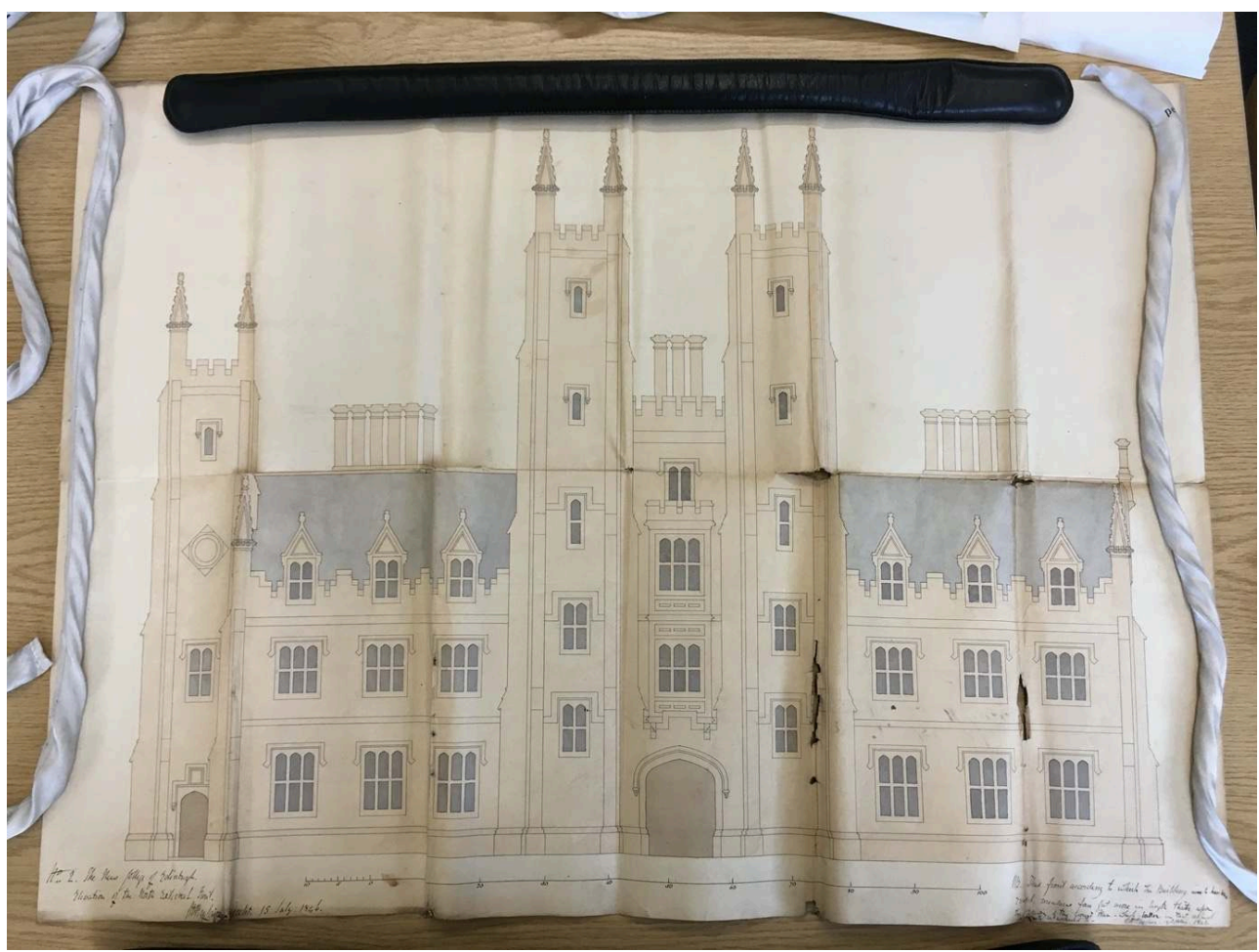

Copyright Edinburgh City Archives 


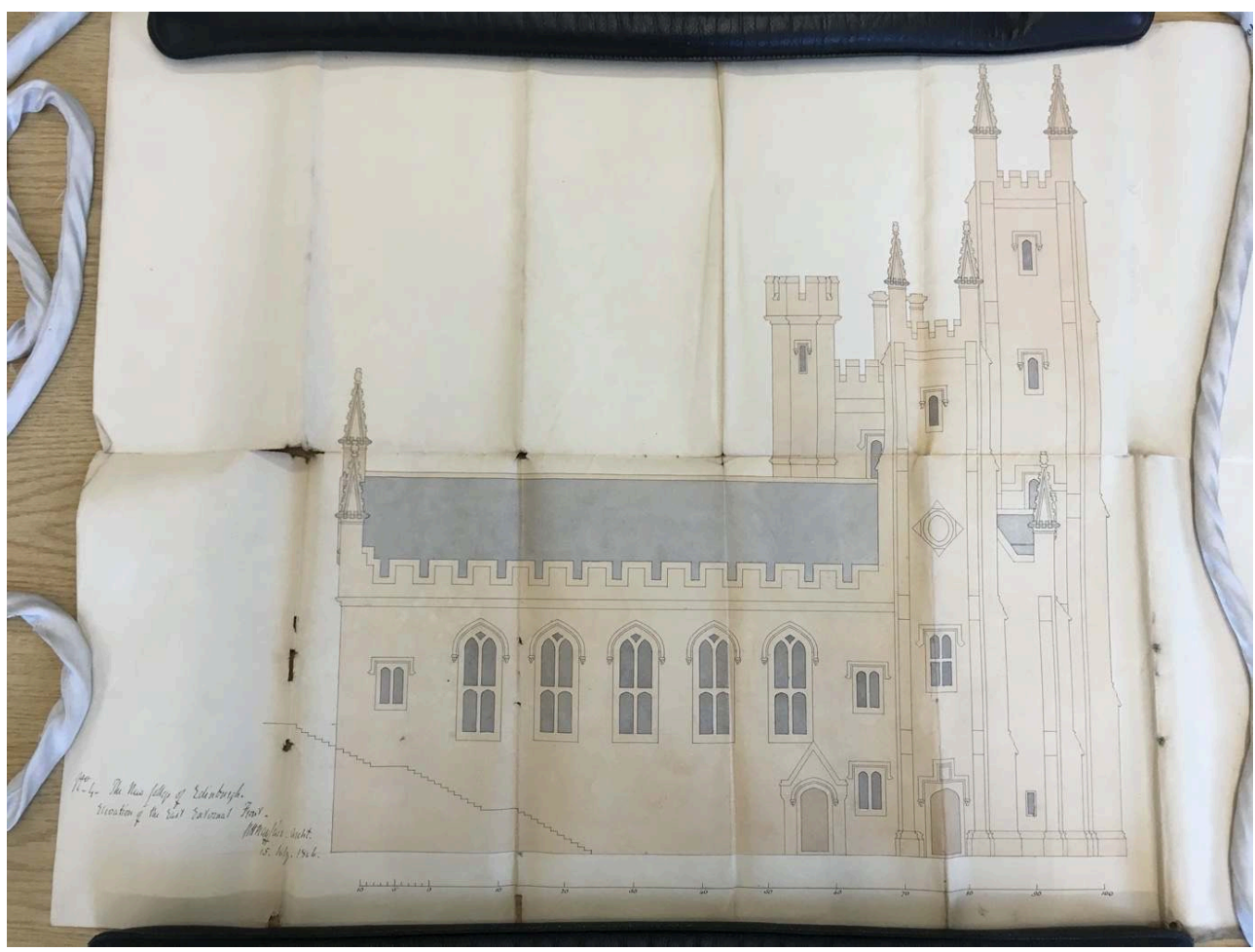

Copyright Edinburgh City Archives.

In July 1847, regarding a statue to Chalmers who had died on 31 May, Playfair wrote:

I have been anxiously endeavouring to find out the best place for the proposed statue of Dr Chalmers, to whose memory it is impossible to pay too much respect. I send a sketch pointing out the position that has occurred to me, if it be placed within the walls of the college. I think the statue would stand nobly at the east end of the library. There would be a side light from the Quadrangle. And I can contrive the Roof in much a way as to throw down a stream of light from above, in the most favourable manner for producing a good effect upon the sculpture. And the apartments below being arched there will be plenty of strength to bear up the great weight of the marble [...] PS. If the new assembly hall be built the statue will be still more seen if placed in that building. ${ }^{27}$

By then, difficulties which had arisen over the foundation of the building had been resolved. Playfair thought it necessary that the foundation should be carried down to the rock, at an additional cost of $£ 1,800$. The construction of the church relied solely upon individual contributions with an original appeal to twenty individuals, who contributed $£ 1,000$ each. ${ }^{28}$ Further appeals were made to clear the debt, including in 1850. ${ }^{29}$ The Heads of Agreement between the College Committee and the Deacons' Court of the Free High Church Congregation of Edinburgh, dated January 1848, refers to the building contract for the erection of the New College and Church dated 17 March 1847 entered between a sub-committee of the College Committee, Playfair the architect, and Alexander and Robert Smith, builders in Edinburgh. ${ }^{30}$ The building was to be completed by Martinmas 1849. Payment was made to Messrs Maclure and Macdonald for a lithographic print of the Free College, at a cost of $£ 28.7 .6 .{ }^{31}$ In September 1848 Playfair wrote that there was no present need to insure the buildings because of there being so 
little that was inflammable, "But when the roof of the Church is ready for the sarking \& for the plumber work, I would recommend a small insurance, say, for 300 pds. And when the joiners begin to work in the interior this should be increased to $5000 \mathrm{pds}$ and again as the work advances". ${ }^{32}$ In 1849 , Playfair recommended that in order to obtain space for a building fitted to serve as a church and an assembly hall, "the whole of the property extending to the close immediately to the west of Mylne's Court must be bought \& cleared away". Such an extension was carried out by David Bryce ten years later (see below). ${ }^{33}$ In September 1850, a contract was signed between Playfair and the builders to fit up a library in the three attic rooms of the building for the sum of £163.2.8. ${ }^{34}$ The introduction of gas into the Church was intimated by Playfair in 1849, and the payment for the water duty settled in $1841 . .^{35}$

The building was opened on 6 November 1850 with an official meeting in the Common Hall at noon to celebrate the achievement and, in the evening, a dinner at the British Hotel (most subscribers residing in enviable locations in the New Town). ${ }^{36}$

Stylistically, the building is in the English collegiate style, combining the common Tudor with some of the later Gothic, and arranged to form an open quadrangle entered by a groined archway; the Free High Church is situated on the east of the courtyard. The principal's house occupies the south-east block in the lower quadrangle. The College north quarter has two square towers (each with four crocketed pinnacles), and a third tower moved away from the central gable of the church, to the east - a variation of the standard church formula of placing an entrance tower central on the gable (as seen for instance at St John's Church, on Princes Street, below). This had the effect of maximising the north quarter's show front while buttressing the sense of its resilience above the declining terrain. At basement level (plan of 4 February 1846), on one side of the archway is the porter's house and, on the other side, a senate hall beyond which, and separated, is a vestry connecting into the church by steps. Inside the church, the pulpit, ministers' pew and elders' pew are situated to the north, with a gallery on the south. Two classrooms feature on this level (one in the west quarter accessible via the courtyard, and one in the north-west corner) (Figure 17). 
Figure 17: The New College of Edinburgh, Plan of Basement Floor, No.8, by William Playfair, 1846

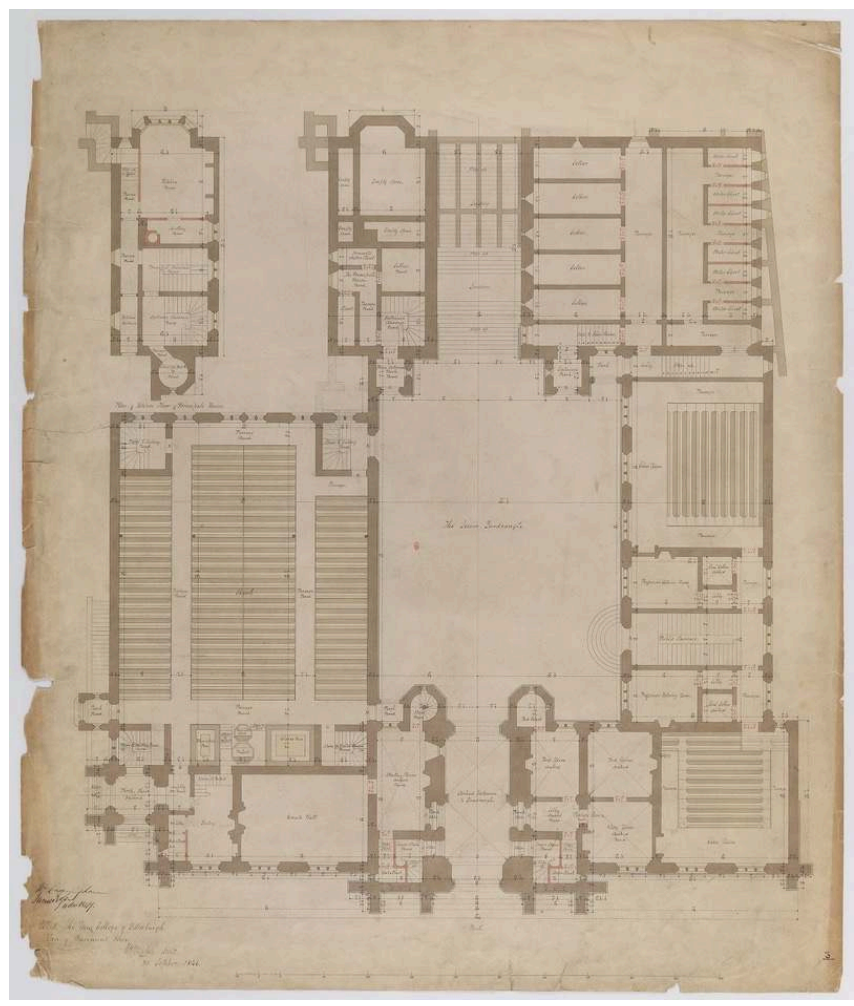

Source: Centre for Research Collections, The University of Edinburgh, George Square. https:// images.is.ed.ac.uk/luna/servlet/s/7epa90

On the principal floor above the main porch is a reading room and, also in this north block, are a waiting room, a session house and a library (Figure 18). 
Figure 18: The New College of Edinburgh, Plan of Principal Floor No.4, by William Playfair, 1846

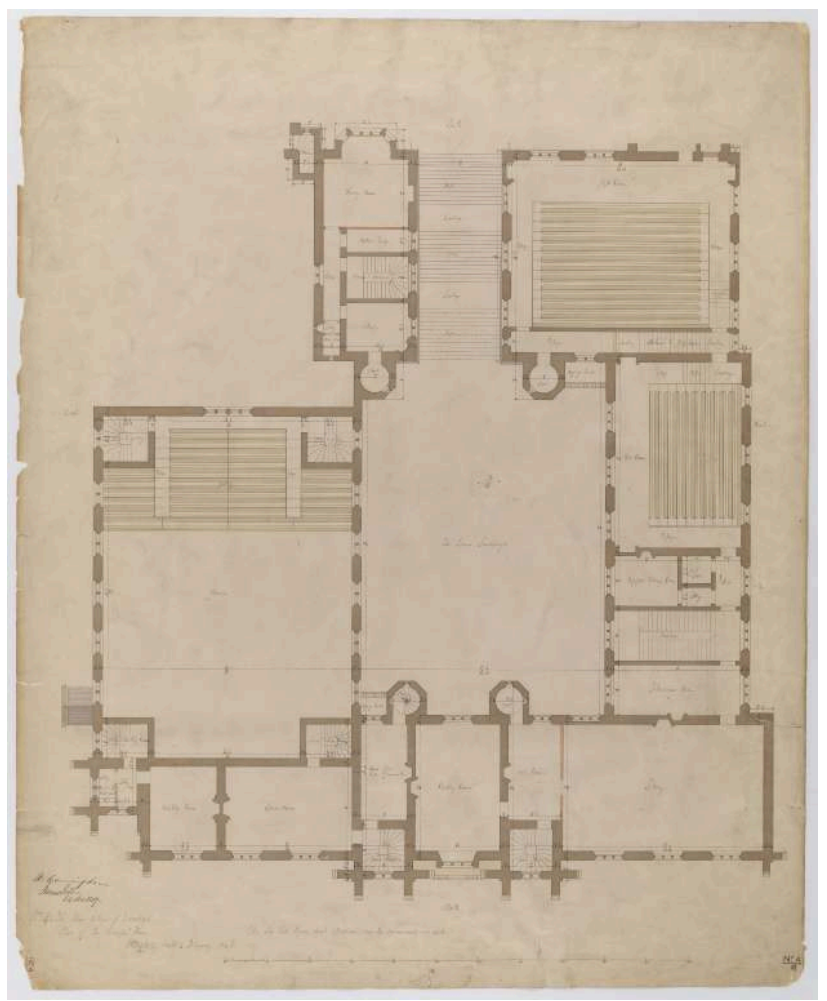

Source: Centre for Research Collections, The University of Edinburgh, George Square. https:// images.is.ed.ac.uk/luna/servlet/s/33v97w

32 Two additional classrooms feature in the south and south-west blocks. At attic level, an upper library stands immediately above the entrance, and five other rooms are described as 'library' in the west block, and south-west and north-west corners. With a further library at roof level, two superimposed libraries stand above the main entrance, facing the courtyard and the Mound on either side.

Considering the vista up Dundas Street, the pinnacles on New College are clearly made to match those of Victoria Hall, and so made to further the pretence of the three towers all belonging to the same building, almost marrying them together (Figures 10 and 19). 
Figure 19: Coloured lithograph showing perspective view of Playfair's front elevation by W. L. Leitch Esq and published by Machire and Macdonald, Glasgow and London, c.1846

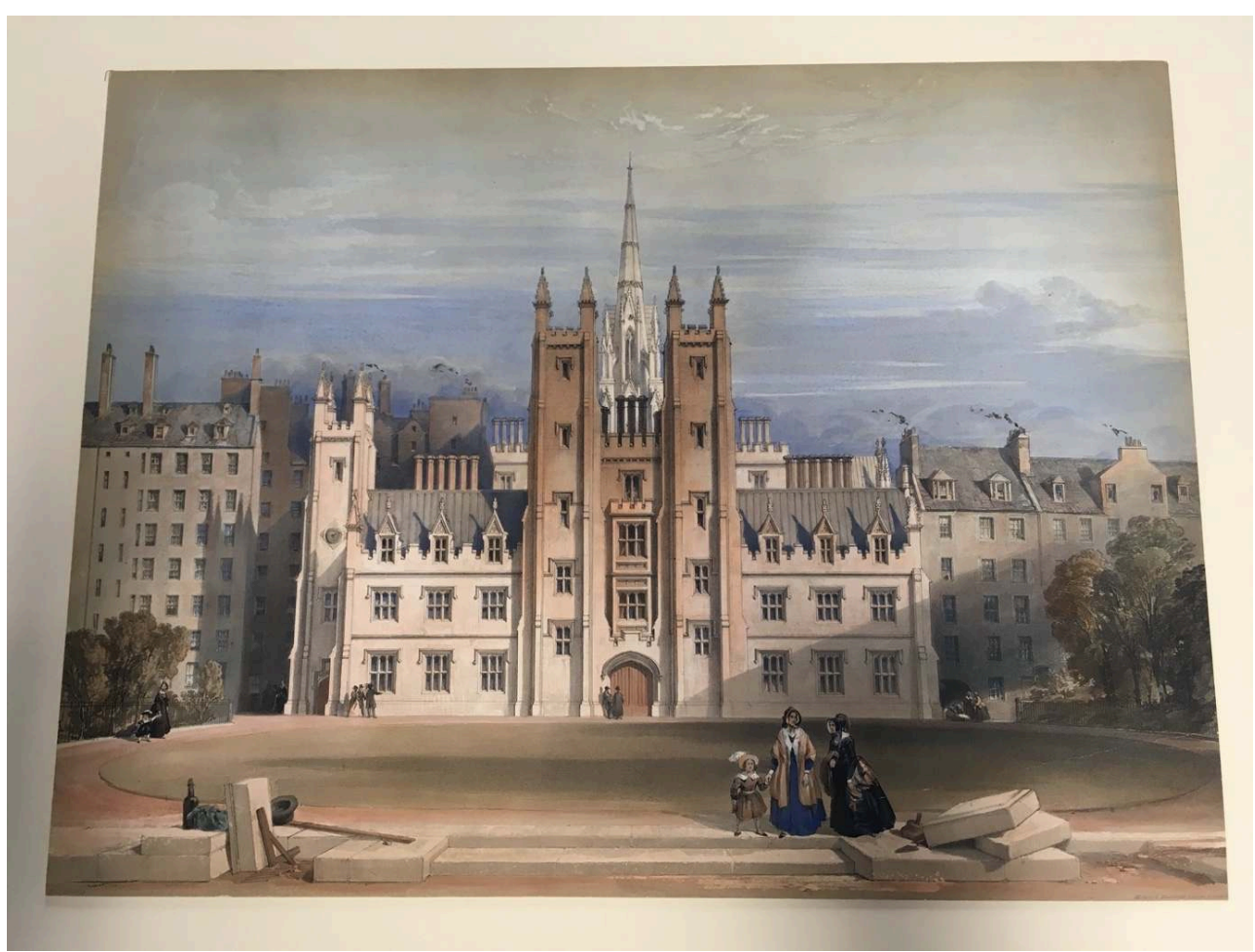

The pinnacles on New College are made to match those of Victoria Hall behind it, as if the three towers belonged to the same building.

Source: Historic Environment Scotland, UC 5998.

The pinnacles of course repeat a standard Gothic formula, one already used by William Burn at St Giles, but here the pinnacles at New College and at Victoria hall are much more slender - and matching. The Tudor collegiate formula of New College signalled that it was a place of learning; the same style had been used in the 1820 by John Smith for the reconstructed King's College, Aberdeen.

In broader urban design terms, William Henry Playfair, the architect, deliberately designed his Free Church building so that its twin towers framed the huge spire of the Victoria Hall, thus visually and symbolically uniting the two buildings of the divided Church and providing a powerful visual axis through the city, uniting New Town and old Town, and linking the buildings all the way to Tanfield where the disruption ministers held their own first assembly. Playfair designed this powerful visual statement into the city at the same time that he was designing the physical link between Old and New Towns, and at the same place. The perfect symmetry of Playfair's building is shown on a c.1846 lithograph (Figure 19), with the flat front terrace disregarding the reality of the steeply-sloping terrain.

The stairs on the south side of the quadrangle leading to the Free Assembly Hall were added in 1858-9, after designs by David Bryce; the site was purchased on 13 March 1858. It was reported that:

A committee of the Free Church General Assembly have purchased an extensive area on which to build a new hall of Assembly. Plans are in preparation for the proposed building, which is expected to cost about 7,000l. It will have a frontage of an ornamental character towards the Castlehill, and is to provide accommodation 
for at least 2,000 persons. The building will be situated immediately in the rear of the Free Church College, and will close up the south side of its quadrangle, thereby completing it. The hall will thus also be accessible from Mound-place, by the broad staircase ascending from the quadrangle. (The Builder 1858: 183) 1890s, in particular because of the growth of the library, a scheme for an extension of the premises was adopted to coincide with the celebration of the Jubilee of New College, in 1900. Plans were prepared by Sydney Mitchell (1856-1930) of Sydney Mitchell and Wilson in 1899, with the overall cost expected to exceed $£ 10,000$.

The Upper Library was greatly expanded by the incorporation of the two adjoining classrooms. Two new classrooms and a Societies' room were provided in what came to be known as the Ramsay Lane wing. The Rainy Hall was built on the ground between that wing and the Assembly Hall [...] A new kitchen was installed to the south of the Rainy Hall; and a corridor along its north side connected the main building with the Ramsay Lane wing. Improvements were effected in the west quadrangle. The Common Hall, now superseded as a Dining Hall, became a much better general reading-room, while the demand for a quieter place for the consultation of books was met by assigning to that purpose a portion of one of the two classrooms annexed by the Library. (Watt 1946: 83-4)

Sydney Mitchell and Wilson also altered the doors leading to the Assembly Hall from the quadrangle and, as quoted, designed the Rainy Hall west of the Assembly Hall. It has 3-metre high panelled-walls with painted shields at the top of the panels, and more shields at the corbels from which springs the elaborate painted and gilded hammerbeam roof (Gifford 1984: 185). By then, Sydney Mitchell was a sought-after architect who restored the Market Cross, in Edinburgh, and experimented a variety of styles; his housing developments at Well Court and Ramsay Garden were both in the neo-baronial style and, at Barnbougle Castle for the Earl of Rosebery, Mitchell referenced the Scots Renaissance (specifically, Linlithgow Palace).

David Cousin (1809-78), a Whig Free Churchman and a former pupil of Playfair, was commissioned to design the Free Church offices and Savings Bank in 1858-63. This comprised a pair of $18^{\text {th }}$-century tenements above the Mound (15-16 North Bank Street) and directly to the east of New College. Cousin produced an outstanding picturesque neo-Jacobean design enhancing the old Town skyline while, like New College itself, addressing the New Town. These buildings are now used as a training college for the Free Church. Like Playfair, David Cousin joined the newly-formed Free Church at the Disruption. The College has a high five-storey and attic front divided into two unequal parts by a pavilion-roofed tower (Gifford 1984: 179, 196). Although the superimposed windows give the north façade an air of gravity, Cousin used detailing and buckle quoins derived from Heriot's Hospital, Scotland's greatest Renaissance building; by 
doing so, Cousin was referencing ancient Scottish buildings, and such motifs of Scottish Revivalism were repeated elsewhere in the Old Town, like in the elaborate strapwork at the school built by George Smith, 1844-45, on the western approach (now 14-15 Johnstone Terrace). The overdoor sculpture on Cousin's north front of the College is informative; the sculpture includes the date 1843 besides its actual datestone of 1860 . The Burning bush symbol and Latin motto 'nec tamen consumebatur' (Figure 20) deployed within a medallion above the entrance was historically that of the Church of Scotland, meaning that the Free Church saw itself as the 'real' Church of Scotland, and therefore retained the 'logo'. Artist D. Y. Cameron gave it its standardised form in 1930; significantly, to please everyone in the new united Church (unification occurred in 1929).

Figure 20: Overdoor sculpture on Cousin's north front of the Free Church College

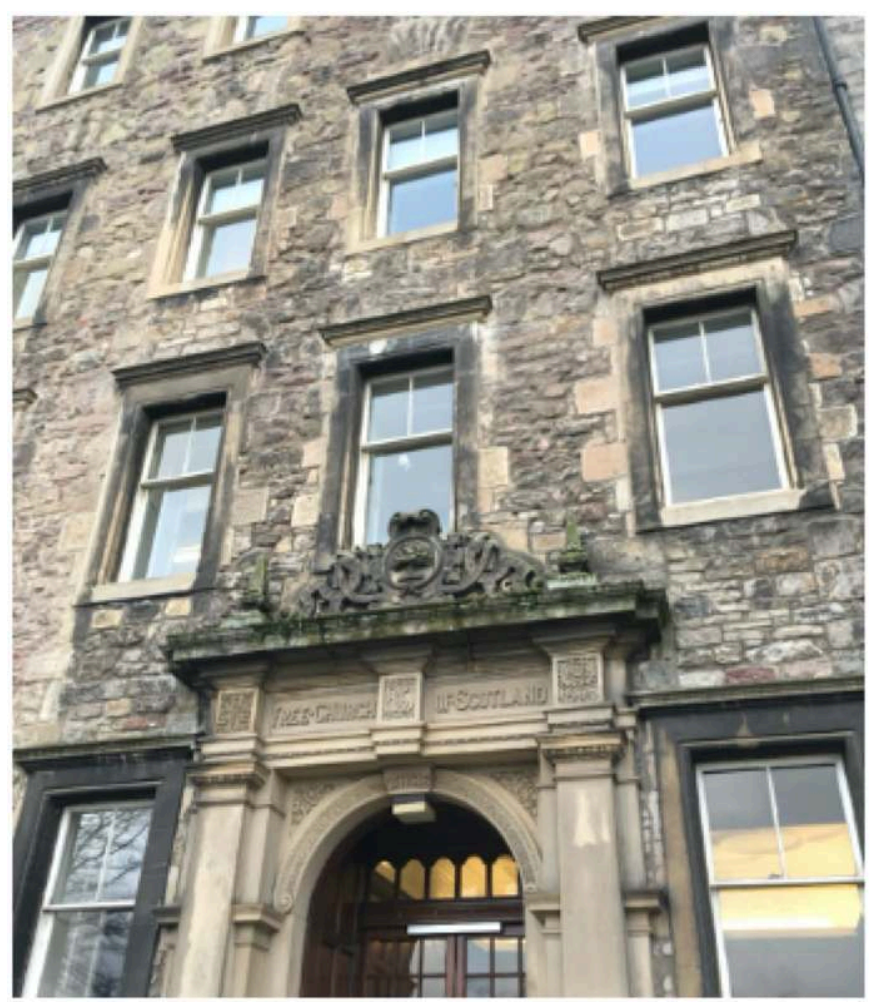

Picture taken by the author.

David Cousin had in fact been providing architectural advice in 1844 for the New Free College before the launch of the above-mentioned official competition; the Free Church was at that point hoping to erect a college which would be a credit to the church on what afterwards would have seemed a comparatively meagre $£ 20-25,000$ budget (this of course preceded the enthusiasm in favour of building the College, and inflation of the budget ultimately available) (Brown 1884: 329):

Strict attention to economy being the sole aim, and carried to an extent not hitherto attained, in the designs prepared for the committee all regard to mere architectural effect, or professional habits and predilections was of necessity excluded. In a merely professional point of view therefore nothing could have been more irksome and uncongenial to my previous tastes than the duties thus assigned me. ${ }^{39}$ 
Sydney Mitchell and Wilson also made piecemeal additions and alterations to this building in 1891-c.1905 mainly relating to classrooms, panelling and heating systems, but externally, it remains much as Cousin left it. ${ }^{40}$

\section{Conclusion}

The building of Victoria Hall and Free Church evidence two rival national institutions making it clear they each regarded Edinburgh as the national capital and therefore the only option for locating their headquarters. While the Church of Scotland built its training college in Glasgow, the Free Church based itself entirely in the capital. From Edinburgh came the inspiration for what was to be disseminated to all parts of the country and beyond. "The constitution of this college is the same as that of the Free Church colleges elsewhere" (Grant 1881: 97). Students of Divinity came from all parts of the Empire, as the prestige of the training offered by the Edinburgh College grew in the course of the $19^{\text {th }}$ century. The Free Church and the Church of Scotland were important in people's lives, and reminders of this can be seen in public sculpture: a statue of Rev. Thomas Chalmers designed by John Steell in 1878 was erected on a George Street crossroads in a position fully as prominent as that of King George IV (statue by Sir Francis Chantrey, 1831); also, a statue of John Knox, designed by J. Hutchison RSA, was placed in the quadrangle of New College in 1896, thereby 'claiming' the Free Church as the prime product of the Scottish Reformation of 1560.

The twin towers of the Free Church building took their place midway between the old Edinburgh and the New, and the respective presence of the two churches in the urban landscape suggests a battle of the spires; the spire of Victoria Hall was even higher than the Castle. The construction of the Free Church was to embody the power of the newlyestablished institution; Chalmers in his speech hoped that the Free Church building 'would shortly [...] arise in graceful superstructure to delight the eye [...] of admiring citizens' (Watt 1946: 3). He never saw it completed, having died in 1847. The fact that many congregations had been forced to place their churches out of sight, in back lanes - though some such as Musselburgh did find prominent sites - rendered it only the more important to have the Free Church College set advantageously in clear public view. The Gothic style of both Victoria Hall and the Free Church contrasted with Playfair's Greek Revival Royal Institution (1822-26 and 1832-35) and National Gallery (1850-57) at the foot of the Mound below, and the contrast adds to the buildings' prominence.

Here, in the fine perspective of the High Street and the Lawnmarket, that prestige of grandeur - arising from the simultaneous look of antiquity and modernity of the two churches - persisted, where not far away poverty otherwise frequently prevailed. The social mission of the Churches, and their missionary role, was important in the context of the Empire, and both Churches celebrated Britishness within Scotland - a point on which they agreed. But they took opposing views on the role of the UK's monarchy within that arrangement, which led to there being not one, but two buildings for discussion in this paper.

The link made at the beginning of this paper with 'Holy Corner' in the Morningside district of the city is apposite, but also contrasting, because we see here the toleration of a greater diversity of Christian belief in a middle class, inner suburb whose influence 
in the city expanded in the Victorian era. In this case study, we witness a schism and later reconciliation within the post-Reformation, Presbyterian Church of Scotland the Established Church of the country (after unification in 1929).

\section{BIBLIOGRAPHY}

\section{Unpublished Sources}

Edinburgh University Library, New College, AA 1.5.10, AA 1.5.11, AA 1.5.12, Correspondence and Memoranda.

National Records of Scotland, MW5/188, MW5/197, MW5/204, RHP6501/57-58.

Edinburgh City Archives [ECA], Dean of Guild Petition, Commissioners of Her Majesty's Woods, Forests, Land Revenues, Works and Buildings for Leave to build a new Church and Assembly Hall, 4 February 1841.

ECA, Dean of Guild Records 15 April 1865, 16 June 1865.

ECA, Dean of Guild Court, Petition by A. E. Monteith, Esqr, and Others for Warrant to Build New College at the head of the Earthen Mound, 29 October 1846.

ECA, Petition of the Trustees for the Free Church of Scotland, 1858, extracted 17 July 1858.

ECA, Four designs by David Bryce of the Free Church Assembly Hall, 23 June 1858.

Historic Environment Scotland, SMW 1890/29/1-10.

\section{Published Sources}

The Scottish General Assemblies. Tinsleys' Magazine, vol. 5 (Dec. 1869): 595.

ART. I. - Proceedings of the General Assembly of the Free Church of Scotland, which Met in Edinburgh, May 22, 1851. The Biblical Repertory and Princeton Review 23(4) (Oct. 1851): 575.

Brown, Stewart J. The Disruption and the Dream: The Making of New College 1843-1861. In David F. Wright and Gary D. Badcock (eds.). Disruption to Diversity: Edinburgh Divinity 1846-1996.

Edinburgh: T\&T Clark (1996). 29-50.

Brown, Thomas. Annals of the Disruption with Extracts from the Narratives. Edinburgh: Macniven \& Wallace, 1884 .

Fraser's Magazine, July 1856, November 1848.

Gifford, John et al. The Buildings of Scotland: Edinburgh. Harmondsworth: Penguin, 1984.

Glendinning, Miles. The Architecture of Scottish Government from Kingship to Parliamentary Democracy. Dundee: Dundee University Press, 2004.

Gow, Ian. William Henry Playfair. In Scottish Georgian Society, Scottish Pioneers of the Greek Revival. Edinburgh: Scottish Georgian Society, 1984. 43-55. 
Grant, James. Old and New Edinburgh. Vol. 1. Edinburgh: Cassell, 1881.

Grant, James. Old and New Edinburgh. Vol. 3. Edinburgh: Cassell, 1885.

Groome, Francis H. (ed.). Ordnance Gazeteer of Scotland. Edinburgh: T.C. and E.C. Jack, 1901. [online access at https://digital.nls.uk/gazetteers-of-scotland-1803-1901/archive/97393254].

Haynes, Nick and Clive B. Fenton. Building Knowledge: An Architectural History of the University of Edinburgh. Edinburgh: Historic Environment Scotland, 2017.

https://canmore.org.uk/site/235638/edinburgh-7-victoria-terrace-quaker-meeting-house

https://canmore.org.uk/collection/1026353

https://canmore.org.uk/site/20194/aberdeen-kings-college?display=collection\&per_page=127

https://canmore.org.uk/file/image/353920

http://www.scottisharchitects.org.uk/architect_full.php?id=200250

Lauder, Thomas D. Memorial of the Royal Progress in Scotland. Edinburgh: A. and C. Black, 1843.

Lizars, William H. Plan of Edinburgh and Leith. Edinburgh: Ballantyne and Co., 1856.

Macaulay, James. "The Architectural Collaboration between J. Gillespie Graham and A. W. Pugin.” Architectural History 27 1984: 406-420.

Pugin, Augustus W. N. The True Principles and Revival of Christian Architecture. Edinburgh: John Grant, 1895.

The Builder, 13 March 1858, 19 August 1865, 4 November 1865.

Watt, Hugh. New College Edinburgh; A Centenary History. Edinburgh: Oliver and Boyd, 1946.

Williams, Matthew. "Planning for the Picturesque: Thomas Hamilton's New Roads to the Old Town, 1817-1858." Architectural Heritage 20(1) 2009: 3-53.

\section{NOTES}

1. In 1633, Charles I made St Giles the cathedral of the Diocese of Edinburgh. St Giles lost cathedral status after the restoration of Presbyterianism in 1638, but served again as a cathedral during the ascendancy of episcopacy between 1661 and 1690.

2. Treasury to Commissioner of Woods and Forests, 9 May 1834. Precis of Papers on the Subject of the Hall for the Meetings of the General Assembly of the Church of Scotland. From the year 1829 to 1839 (1839). National Records of Scotland [hereafter NRS], MW5/204.

3. Woods and Forests to the Treasury, 30 May 1834. NRS MW5/204.

4. Woods and Forests to Treasury, 25 March 1836. NRS MW5/204.

5. Gillespie Graham's estimates, 21 April 1837. NRS MW5/204.

6. Memorial from the General Assembly, 14 December 1838. NRS MW5/204.

7. Office of Works to James Gillespie Graham, 15 November 1839. James Gillespie Graham to Chief Commissionner of Woods, 2 March 1840. NRS MW5/204.

8. On James Gillespie Graham, see http://www.scottisharchitects.org.uk/architect_full.php? $\mathrm{id}=200250$.

9. Edinburgh City Archives [hereafter ECA], Dean of Guild Petition, Commissioners of Her Majesty's Woods, Forests, Land Revenues, Works and Buildings for Leave to Build a New Church and Assembly Hall, 4 February 1841. 
10. Matthew Williams, 'Planning for the Picturesque: Thomas Hamilton's New Roads to the Old Town, 1817-1858', Architectural Heritage, 2009, 20.1 : 3-53.

11. See, for e.g., Report of the Sub-Committee of the General Committee on the Improvement of the Assembly Hall, 19 November 1855 . NRS MW5/188.

12. James Gillespie Graham to Commissioners of Woods and Forests, 12 January 1843. NRS MW5/197. 'Estimate by Charles Trotter, Edinburgh, January, 1843.' NRS MW5/197.

13. James Gillespie Graham to Commissioners of Woods and Forests, 12 January 1843. NRS, MW5/197. Proposed design of the Royal Arms for the front of the Gallery, 1843. NRS RHP6501/57. Plan of proposed design for Clock Dial, 1843. NRS RHP6501/58.

14. James Gillespie Graham to Henry Hake Seward, 4 February 1843. NRS MW5/197.

15. 'New College', signed by William Cunningham, convener of the College Committee, and Alex.

E. Monteith, Convener of the Building Committee, 1850. Edinburgh University, New College, AA 1.5.12, Correspondence and Memoranda.

16. Alexander Stuart to Maurice Lothian, 6 June 1843. Maurice Lothian to Archibald Bonar, 29 June 1843. Alexander Stuart to Maurice Lothian, 16 August 1843. See also Maurice Lothian to James Bonar, 11 July 1845, for details of the property purchased on 80 George Street. Edinburgh University, New College, AA 1.5.10, Correspondence and Memoranda.

17. Free Church of Scotland, Report of the New College (Edinburgh: John Greig, 1848). Edinburgh University, New College, AA 1.5.11, Correspondence and Memoranda.

18. A. E. Monteith to C. Barry, 22 January 1845. Barry to Monteith, 27 January 1845. David Welsh to Charles Barry, late January 1845. New College, AA 1.5.10.

19. Barry to Committee for erecting the proposed college for the Free Church of Scotland in Edinburgh, 11 February 1845. New College, AA 1.5.10.

20. Thomas Morrison to John Auld, esq., 14 August 1845. New College, AA 1.5.10.

21. Report to the Committee of the Free Church regarding the New College of Edinburgh, Edinburgh April 1846. New College, AA 1.5.11.

22. Ibid.

23. Playfair to Building Committee, 2 April 1846. New College, AA 1.5.11.

24. Playfair to Monteith, 4 June 1846. New College, AA 1.5.11.

25. Petition by A. E. Monteith, Esqr, and others for warrant to build New College at the head of the Earthen Mound, 29 October 1846. ECA, Dean of Guild Court.

26. Alexander Robert Smith to Playfair, 2 November 1846. New College, AA 1.5.11.

27. Playfair to Committee, 23 July 1847. New College, AA 1.5.11.

28. To the Marquis of Breadalbane, 18 January 1848. New College, AA 1.5.11.

29. The debt on the Building Fund to be cleared amounted to $£ 8,000$ in 1850 . New College Building Fund, July 1850, signed Robert Buchanan. New College, AA 1.5.12.

30. New College, AA 1.5.11.

31. Playfair to James Bonar, 17 April 1848. New College, AA 1.5.11.

32. Playfair to James Bonar, 18 September 1848. New College, AA 1.5.11.

33. Playfair to A. Earle Monteith, 6 December 1849. New College, AA 1.5.12.

34. Minute of Agreement between William Henry Playfair Esquire Architect acting for behoof of the New College Committee and Messrs Alexander and Robert Smith Builders, 20 September 1850. New College, AA 1.5.12.

35. Playfair to unknown, 24 September 1849. Water Companys Office to James Bonar, 25 April and 9 May 1851. New College, AA 1.5.12.

36. Opening of New College, Subscribers ticket, dinner at the British Hotel. New College, AA 1.5.12.

37. ECA, Petition of the Trustees for the Free Church of Scotland, 1858, extracted 17 July 1858.

38. ECA, Four designs by David Bryce of the Free Church Assembly Hall, 23 June 1858. 
39. David Cousin to Dr Welsh, 30 May 1844. New College, AA 1.5.10, Correspondence and Memoranda.

40. Historic Environment Scotland SMW 1890/29/1-10.

\section{ABSTRACTS}

This paper reflects on the importance of Edinburgh's Lawnmarket and Castlehill area in the context of the 1843 Disruption which saw the separation of the Free Church from the Established Church of Scotland mainly over the issue of the Church's relationship with the State. Edinburgh's Holy Corner, as it is colloquially known, refers to the Bruntsfield and Morningside junction with four churches; but this paper argues that by the mid-19 ${ }^{\text {th }}$ century the Lawnmarket area was an even 'holier' corner. Within a discrete area west of St Giles - Edinburgh's Cathedral - and almost touching one another were built the Church of Scotland's headquarters at Victoria Hall (or Old Tolbooth Church; today, 'The Hub'), and for the Free Church, its headquarters at New College. These two buildings alone (other churches were constructed in closest proximity) show that for both organisations, Edinburgh in its old role as the national capital was deemed vital. This national importance was here emphasised (or resurrected) and intentionally exploited by each organisation for the purpose of demonstrating its own historical legitimacy and validity, each regarding itself as the national Church continuing. That it was not simply Edinburgh, but the Old Town, which was chosen, emphasised yet further the heritage, continuity and historic validity claimed by the two 'ancient' Churches; the Tron Church was a lesser ornament, as the fire of 1824 had diminished its prestige of antiquity. A major - if perhaps inadvertent consequence was that the old Town's renewal was now securely in hand thanks to these competing churches; and all following the effective reincarnation in dressed ashlar of St Giles in the 1830s by William Burn. Both organisations being based in Edinburgh made the city not simply the two Churches' national headquarters, but also, given the impact of missionary work and Empire, the international hub to which every congregation looked to for leadership and support. By focusing on a small area at the very heart of the Old Town of Edinburgh, this paper brings together a key moment of ecclesiastical history, whose significance goes well beyond Edinburgh itself, with important developments in urban design and architectural history.

Cet article s'interroge sur l'importance de Lawnmarket et de Castlehill, à Édimbourg, dans le contexte de la «Grand Rupture » (ou Disruption) de 1843 qui a vu la séparation de la Free Church de l'Église établie d'Écosse (Kirk) - principalement sur la question des relations de l'Église avec l'État. Le Holy Corner d'Édimbourg, comme on l'appelle familièrement, fait référence à la jonction entre Bruntsfield et Morningside et à ses quatre églises; cet article affirme pourtant que le Lawnmarket était un endroit encore plus "saint" au milieu du $19^{\mathrm{e}}$ siècle. Dans une zone clairement identifiable, à l'ouest de l'église Saint Gilles, la Cathédrale d'Édimbourg, et presque se touchant les uns aux autres, étaient construits le siège de l'Église d'Écosse (Kirk) à Victoria Hall (ou Old Tobooth Church; aujourd'hui The Hub) et celui de la Free Church à New College. Ces bâtiments (d'autres églises étaient construites à proximité) montrent que, pour les deux institutions, le rôle ancien d'Édimbourg en tant que capitale nationale était jugé essentiel. Cette importance nationale était ici soulignée (ou réactivée) et intentionnellement exploitée par chaque institution dans le but de démontrer sa propre légitimité historique et son fondement, chacune se considérant comme la continuité de l'Église nationale. Le fait que ce n'était pas simplement 
Édimbourg, mais la Vieille Ville, qui était choisie, soulignait encore davantage les valeurs d'héritage, de continuité et de légitimité historique revendiquées par les deux "anciennes » Églises; la Tron Church devenait, à l'inverse, un élément moins important du paysage urbain à la suite de l'incendie de 1824. Une conséquence majeure, quoique sans doute fortuite, était que le renouveau de la Vieille Ville était désormais solidement en marche grâce à la construction d'églises concurrentes; et le tout intervenait après la création d'une belle enveloppe en pierre de taille pour l'église St Gilles par l'architecte William Burn dans les années 1830. Les deux organisations basées à Édimbourg faisaient de la ville non seulement le siège national des deux Églises, mais aussi, compte tenu de l'impact du travail missionnaire et de l'Empire, le centre international vers lequel chaque congrégation en quête de sens et de soutien pouvait donc se tourner. En se concentrant sur une très petite zone au cœur même de la Vieille Ville d'Édimbourg, cet article met en lumière un moment clé de l'histoire ecclésiastique dont la signification dépasse Édimbourg, et dont les répercussions sont importantes pour l'histoire urbaine et l'histoire de l'architecture.

\section{INDEX}

Mots-clés: Édimbourg, architecture, urbanisme, 19e siècle, église, histoire de l'Église, Écosse

Keywords: Edinburgh, architecture, urban design, nineteenth century, church, Church history, Scotland

\section{AUTHOR}

\section{CLARISSE GODARD DESMAREST}

Dr Clarisse Godard Desmarest, FSA Scot, FRHistS is a lecturer in British Studies at the University of Picardie Jules Verne (Amiens) and a fellow of the Institut Universitaire de France. She is author of numerous publications on the history of Scottish architecture and culture, and edited The New Town of Edinburgh: An Architectural Celebration (Edinburgh: John Donald, 2019). Her work has embraced a diversity of topics including the role of women in architecture, the history of the tenement in Scotland and France, the Baronial in $19^{\text {th }}$-century Edinburgh, and other aspects of Early Modern Scotland. Contact: Clarisse.godarddesmarest [at] u-picardie.fr 